\title{
Spatial and Temporal Variations of Water Quality of Mateur Aquifer (Northeastern Tunisia): Suitability for Irrigation and Drinking Purposes
}

\author{
Besma Tlili-Zrelli (iD, ${ }^{1}$ Moncef Gueddari, ${ }^{1}$ and Rachida Bouhlila ${ }^{2}$ \\ ${ }^{1}$ Laboratory of Geochemistry and Environmental Geology, Department of Geology, Faculty of Sciences of Tunis, \\ University of Tunis El Manar, 2092 Tunis, Tunisia \\ ${ }^{2}$ Modeling in Hydraulic and Environment Laboratory, National Engineers School of Tunis, Tunis, Tunisia
}

Correspondence should be addressed to Besma Tlili-Zrelli; besma_fst@yahoo.fr

Received 6 February 2018; Revised 14 April 2018; Accepted 29 April 2018; Published 17 July 2018

Academic Editor: Narcis Duteanu

Copyright (c) 2018 Besma Tlili-Zrelli et al. This is an open access article distributed under the Creative Commons Attribution License, which permits unrestricted use, distribution, and reproduction in any medium, provided the original work is properly cited.

\begin{abstract}
The present study aims to assess the spatial and temporal variations of the hydrochemical characteristics of Mateur aquifer groundwaters, a crucial water resource in the northeast of Tunisia. The aquifer was subject to water quality deterioration due to salinization and nitrate contamination, and a new assessment of water quality was needed. For this purpose, 40 groundwater samples were collected during wet and dry seasons and analyzed for salinity, $\mathrm{pH}, \mathrm{T}, \mathrm{O}_{2}$, major cations and anions, and nutrient elements using standard methods and Water Quality Index (WQI). The results showed that most of the groundwater parameters were not within the permissible limits set by the World Health Organization in both seasons. The geochemical data were interpreted using WQI for drinking water. The spatial distribution maps of Water Quality Index showed that the highest quality was found, during both seasons, in the northwest and the southeast part of the aquifer, corresponding to the recharge zone, whereas the poor and very poor water quality was found in the outflow part of the aquifer. According to sodium adsorption ratio (SAR) and $\mathrm{Na} \%$ values, most of the groundwater samples were not suitable for irrigation purposes and characterizing the eastern part of the aquifer and the outflow part of the aquifer, around the Ichkeul marshes.
\end{abstract}

\section{Introduction}

Groundwater is becoming the major source of water supply for domestic, industrial, and agricultural sectors of many countries all over the world. It is estimated that approximately one-third of the world's population uses groundwater for drinking [1]. Several Mediterranean countries are already facing a situation of severe water quality degradation, mainly due to anthropogenic activities (agriculture, industry, urban development, and increasing exploitation of water resources) as a direct impact of climate change. Water quality is rapidly declining worldwide, particularly in developing countries, due to natural and anthropogenic processes $[2,3]$. Water pollution affects human health, economic development, and social prosperity [4]. The importance of water quality in human health has recently attracted a great deal of interest.

An understanding of the spatial variation and processes affecting water quality is essential in sustaining usable water supplies under changing climate and local environmental pressures. Temporal changes of recharged water composition, hydrologic and human factors, may cause periodic changes in groundwater quality [5]. The quality of alluvial groundwater in rural areas is sensitive to contaminants originating from agricultural chemicals, such as, fertilizers, pesticides, and lime $[6,7]$. The use of nitrogen fertilizers frequently leads to extremely high nitrate concentrations in groundwaters and may cause serious health problems $[8,9]$.

In such circumstances, the knowledge of temporal and spatial trends of water quality should help in the decision-making 


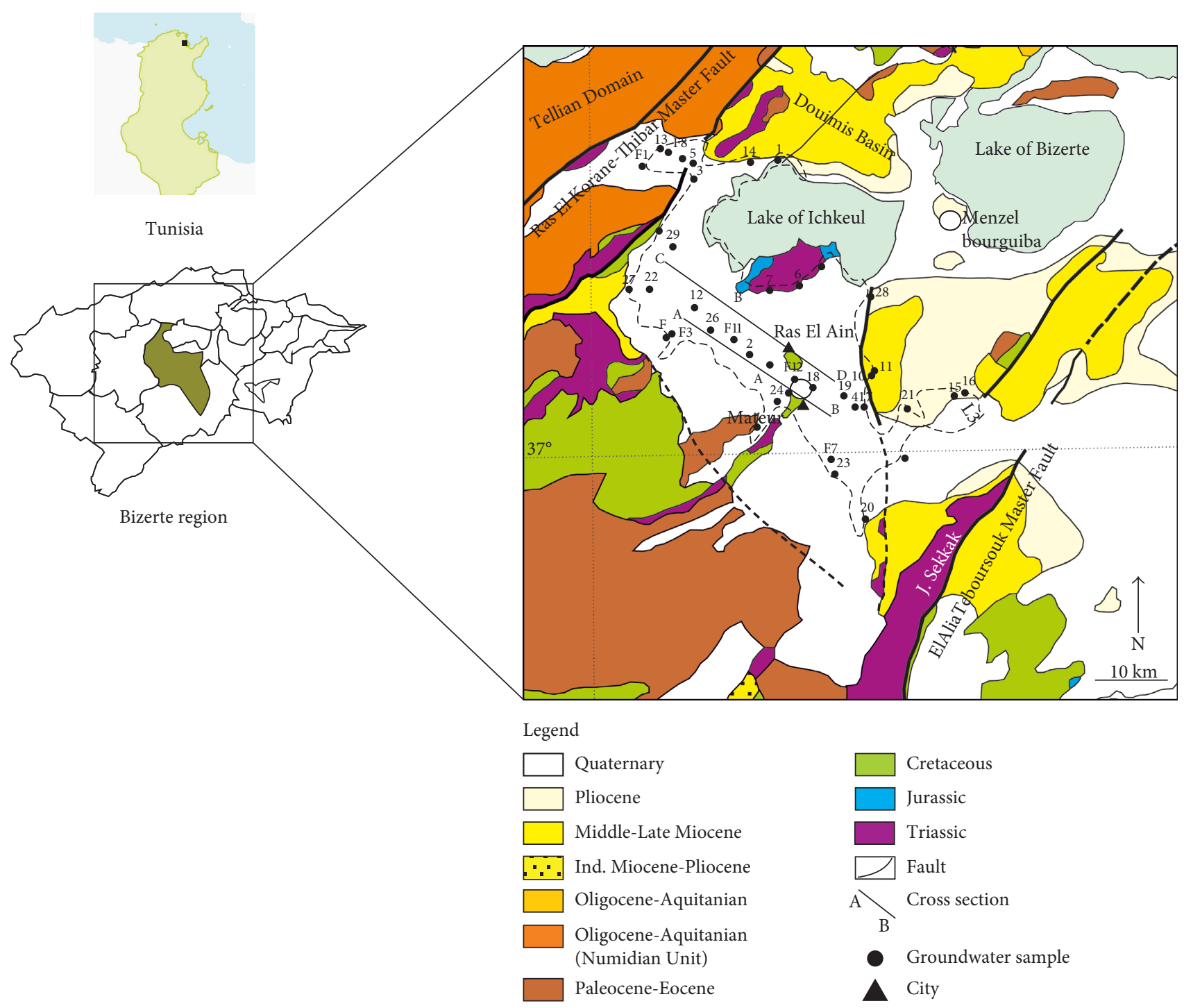

FIGURE 1: Location, geology [14], and sampling points of the study area.

process, particularly in developing countries, where there are insufficient data [10].

In Tunisia, where the climate is dry over most of its territories, water resources are both scarce and unequally distributed through time and space, with a potential decrease, due to overexploitation, exploitation of nonrenewable deep aquifer, salinization, and pollution [11]. Agriculture uses approximately $80 \%$ of all water resources [12]. Mateur alluvial plain is one of the major agricultural regions in Tunisia, and its water resources originate mainly from the alluvial aquifer, which support the local domestic and agricultural water supply with $49 \%$ and $51 \%$, respectively [13]. Although Mateur is not a particularly waterstressed region, brine water around Ichkeul marshes and salty soils contribute to water salinization in some shallow wells. Even more, excessive agricultural activities may be the cause of its water contamination with nitrate.

This paper highlights the spatial and temporal variations in groundwater quality in an alluvial agricultural plain in Mateur region and evaluates the suitability of groundwater

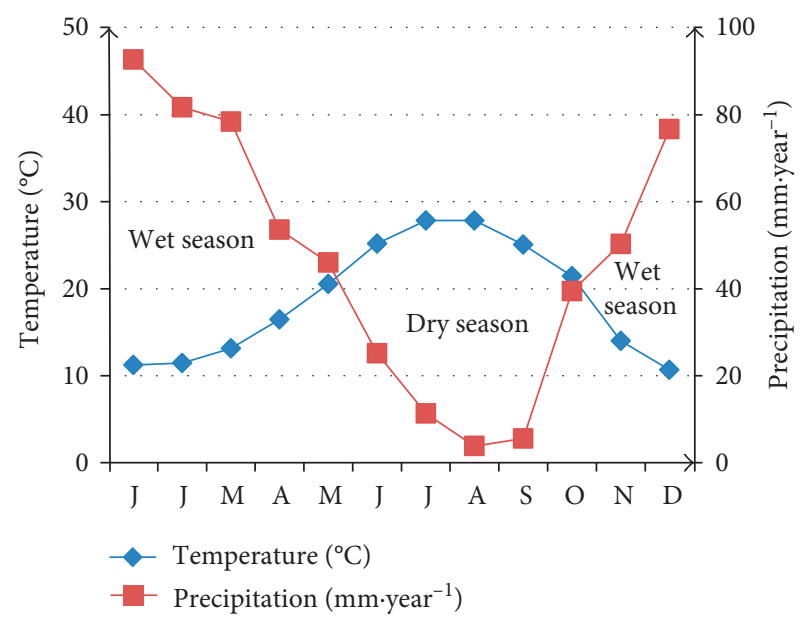

Figure 2: Ombrothermic diagram.

for irrigation and drinking purposes for sustainable agriculture and basic human needs. For these purposes, we used an integrated Water Quality Index (WQI), the sodium 


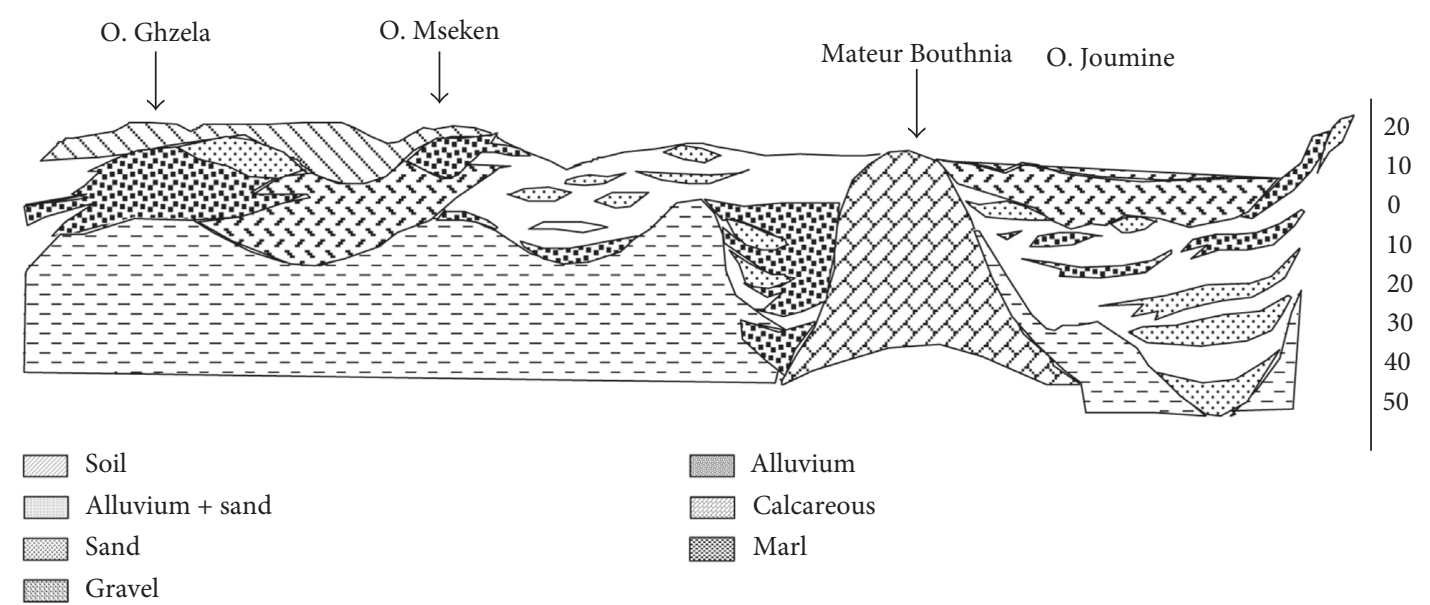

(a)

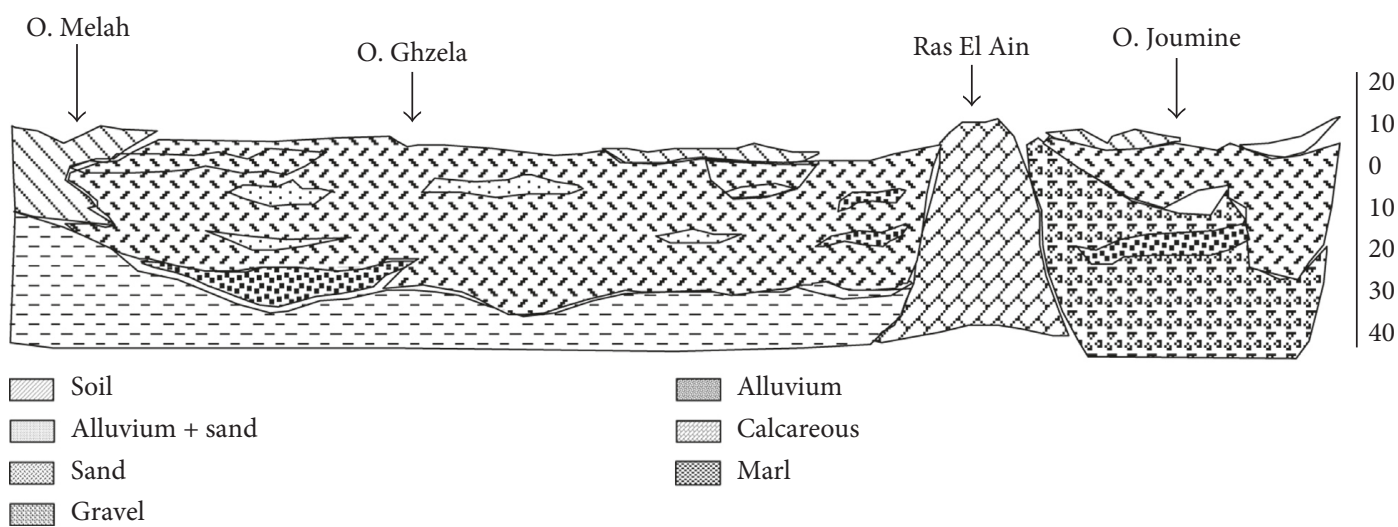

(b)

Figure 3: Hydrogeological cross sections: (a) Mateur and (b) Ras el Ain [15].

adsorption ratio (SAR), the sodium percentage (\% $\mathrm{Na})$, and the permeability index (PI).

\section{Setting and Methods}

2.1. Location and Climate. Mateur plain is located in Bizerte region, in the northeast of Tunisia (Figure 1) and has a surface area of $260 \mathrm{~km}^{2}$ in the vast Ichkeul catchment $\left(2600 \mathrm{~km}^{2}\right)$. The climate is typically Mediterranean, subhumid with a considerable variation in mean monthly temperatures. The coldest month is January, with a mean temperature of $11^{\circ} \mathrm{C}$, and the hottest is August, with a mean temperature of $27^{\circ} \mathrm{C}$. The ombrothermic diagram (Figure 2) shows two periods: a wet period which lasts 7 months from November to May and a dry period which lasts 5 months from June to October. The mean annual precipitation (1998-2008) in the area is $518 \mathrm{~mm}$ and the mean annual evapotranspiration is $1074 \mathrm{~mm}$.

2.2. Geological and Hydrogeological Setting. Mateur plain covers different statigraphic units ranging from Triassic to Quaternary [14]. The stratigraphic sequence primarily consists of carbonate formations, which characterize the Tertiary deposits of Ichkeul Mountains. In the Mateur plain, outcrops prior to Quaternary are found only on the three Campanian hills of Sidi Mbarek, Mateur, and Ras El Ain.
Miocene is mainly developed in the east of Mateur plain and the north of Ichkeul lake, and it is composed of gypsum and marl. The Quaternary and recent alluvium cover the major part of the plain and are composed of silt and detrital formations. The aquifer system is made up of multilayers, which are either saturated or unsaturated [15] (Figure 3). These layers are composed of alluvial, eolien, and minor lacustrine deposits [16]. The main sources of alluvial aquifer recharge are rainfall infiltration and leakage of rivers (Joumine, Tine, Sejnane, Melah, and Rezala). According to piezometric maps (Figure 4), Mateur aquifer groundwater flow is roughly oriented northward in the upstream part of the plain, whereas in the downstream part, it is controlled by the draining action of the Joumine River.

Water loss from the aquifer is through discharge to the lake Ichkeul, evaporation, and pumping for domestic and agricultural purposes. The water table generally lies within $8-10 \mathrm{~m}$ of land surface, facilitating additional groundwater loss via evapotranspiration. The alluvial aquifer has transmissivity values ranging from $2 \cdot 10^{-5}$ to $20 \cdot 10^{-2} \mathrm{~m}^{2} / \mathrm{s}$.

2.3. Soil Type and Agriculture Practices. According to Mori [17], two major soil types are observed in Mateur plain: fluvisol and hydromorphic and holomorphic soils with high salinity. 


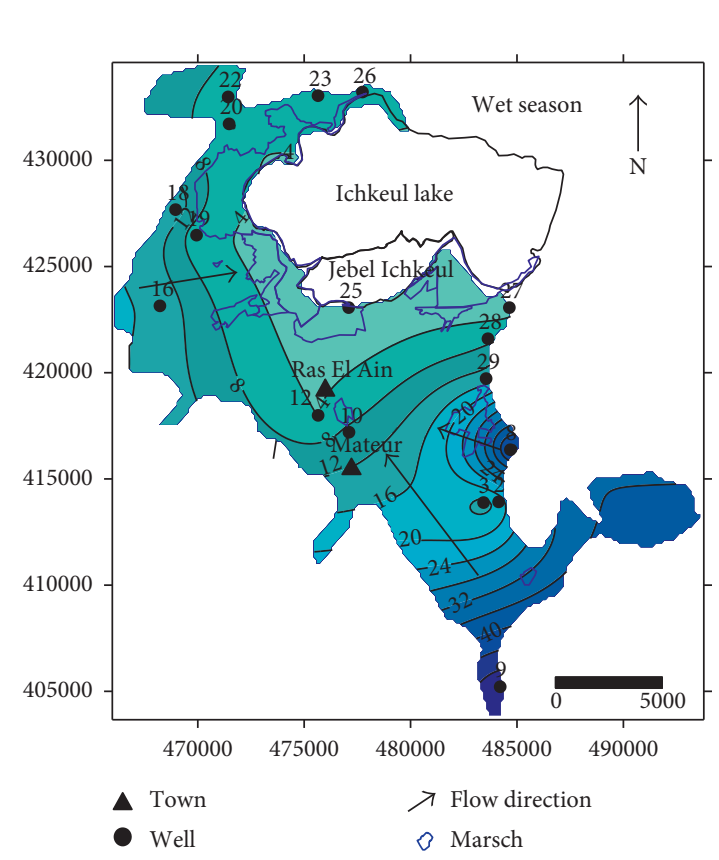

(a)

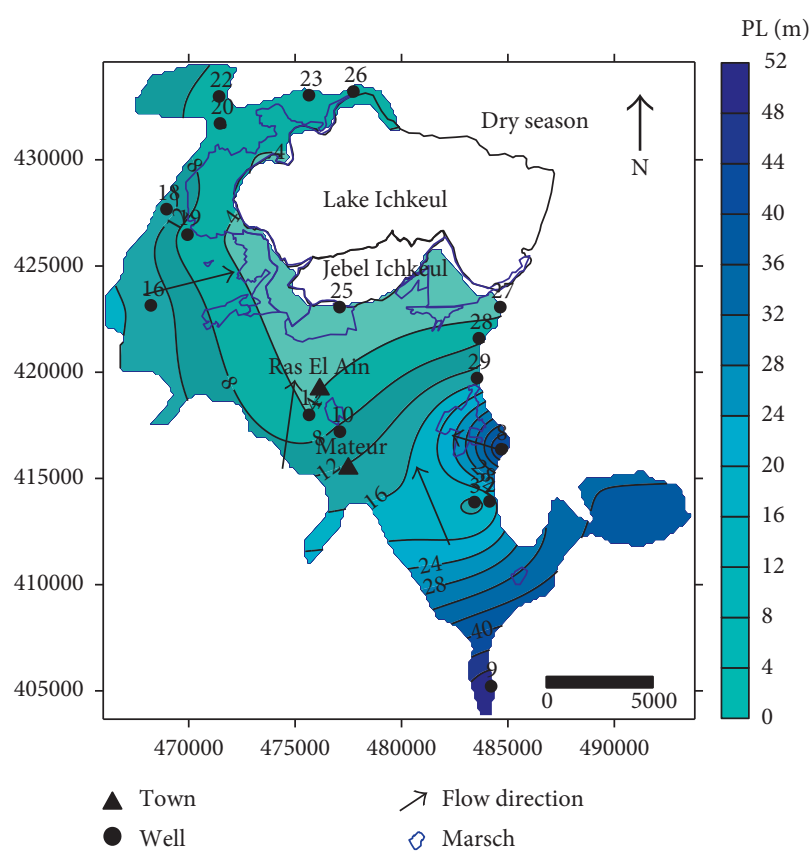

(b)

Figure 4: Piezometric maps of Mateur plain: (a) wet season and (b) dry season.

TABle 1: Details of fertilizer application for different crops in the study area.

\begin{tabular}{|c|c|c|c|c|c|c|c|c|c|c|}
\hline \multirow{2}{*}{ Fertilizer type $\left(\mathrm{kg} \cdot \mathrm{ha}^{-1}\right)$} & \multicolumn{4}{|c|}{ Cereals } & \multicolumn{2}{|c|}{ Fodder } & \multicolumn{2}{|c|}{ Legumes } & \multicolumn{2}{|c|}{ Tree crops } \\
\hline & Nov & Jan & Feb & March & Sept & Jan & Dec & Jan & Oct & Feb \\
\hline DAP N- $\mathrm{P}_{2} \mathrm{O}_{5}$ & 150 & - & - & - & - & - & - & 200 & - & - \\
\hline Ammonium & - & 150 & 150 & 150 & - & 150 & - & 200 & - & 150 \\
\hline Super $45 \mathrm{P}_{2} \mathrm{O}_{5}$ & - & - & - & - & 100 & - & 100 & - & 150 & 一 \\
\hline
\end{tabular}

TABLE 2: Statistical summary of hydrochemical parameters of the study area.

\begin{tabular}{|c|c|c|c|c|c|c|c|}
\hline & \multirow{2}{*}{ Unit } & \multicolumn{3}{|c|}{ Wet season (May) } & \multicolumn{3}{|c|}{ Dry season (October) } \\
\hline & & Min & Max & $\mathrm{SD}^{*}$ & Min & Max & $\mathrm{SD}^{*}$ \\
\hline$\overline{\mathrm{Cl}^{-}}$ & $\mathrm{mg} / \mathrm{L}$ & 67.45 & 2406.90 & 524.66 & 106.50 & 4402.00 & 844.89 \\
\hline $\mathrm{SO}_{4}{ }^{--}$ & $\mathrm{mg} / \mathrm{L}$ & 223.53 & 2483.48 & 497.45 & 221.89 & 3591.36 & 583.38 \\
\hline $\mathrm{HCO}_{3}^{-}$ & $\mathrm{mg} / \mathrm{L}$ & 54.92 & 622.40 & 150.35 & 86.65 & 693.19 & 146.93 \\
\hline $\mathrm{Ca}^{++}$ & $\mathrm{mg} / \mathrm{L}$ & 20.00 & 480.00 & 82.33 & 10.00 & 763.40 & 135.97 \\
\hline $\mathrm{Na}^{+}$ & $\mathrm{mg} / \mathrm{L}$ & 49.00 & 1728.00 & 376.45 & 11.25 & 170.13 & 40.30 \\
\hline $\mathrm{Mg}^{++}$ & $\mathrm{mg} / \mathrm{L}$ & 12.70 & 140.00 & 27.33 & 39.33 & 2576.00 & 491.23 \\
\hline $\mathrm{K}^{+}$ & $\mathrm{mg} / \mathrm{L}$ & 0.78 & 101.60 & 17.84 & 0.00 & 169.00 & 29.88 \\
\hline $\mathrm{T}$ & ${ }^{\circ} \mathrm{C}$ & 16.20 & 26.80 & 2.16 & 18.20 & 26.70 & 1.98 \\
\hline Conductivity & $\mathrm{mS} / \mathrm{cm}$ & 0.54 & 8.64 & 1.94 & 0.72 & 14.59 & 2.98 \\
\hline Salinity & $\mathrm{g} / \mathrm{L}$ & 0.41 & 6.55 & 1.47 & 0.54 & 11.07 & 2.26 \\
\hline $\mathrm{pH}$ & & 6.18 & 8.39 & 0.39 & 7.13 & 9.08 & 0.33 \\
\hline $\mathrm{O}_{2}$ & $\mathrm{mg} / \mathrm{L}$ & 1.20 & 7.60 & 1.36 & 0.60 & 5.20 & 1.09 \\
\hline $\mathrm{NO}_{3}^{-}$ & $\mathrm{mg} / \mathrm{L}$ & 0 & 273.15 & 79.76 & 0.72 & 278.6 & 64.99 \\
\hline $\mathrm{NH}_{4}^{+}$ & $\mathrm{mg} / \mathrm{L}$ & 0 & 6.63 & 1.08 & 0 & 0.2 & 0.03 \\
\hline $\mathrm{NO}_{2}^{-}$ & $\mathrm{mg} / \mathrm{L}$ & 0 & 1.56 & 0.37 & 0 & 0.23 & 0.06 \\
\hline $\mathrm{HPO}_{4}{ }^{--}$ & $\mu \mathrm{g} / \mathrm{L}$ & 10 & 6.37 & 1.02 & 20 & 4.82 & 0.82 \\
\hline
\end{tabular}

*Standard deviation.

Mateur region land is mainly used for growing cereals and fodders. A large amount of synthetic fertilizers (DAP, ammonium, and super 45) are applied during the farming season (winter through spring) [18]. Fertilizer quantities $(\mathrm{kg} / \mathrm{ha})$ and application time are given in Table 1. Almost all farmers apply more than the recommended dose. Besides, over the last few decades, fertilizer management has been dramatically modified, and for economic considerations, 


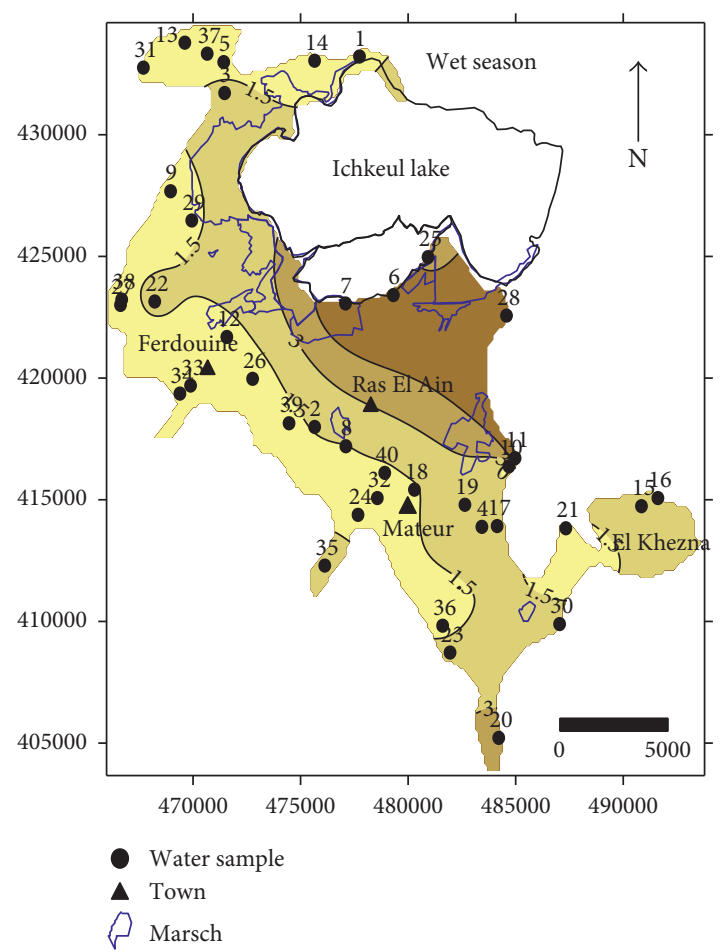

(a)

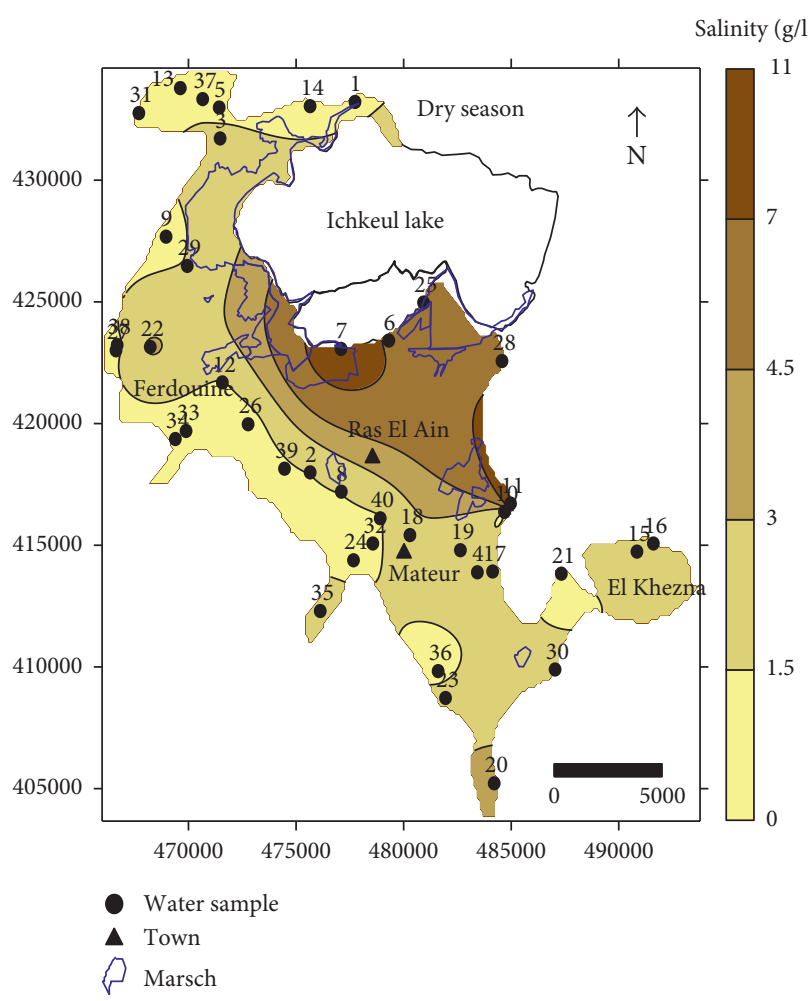

(b)

FIGURE 5: Spatial distribution maps of salinity: (a) wet season and (b) dry season.

crop rotations are rarely applied and cereals are the predominant land use for many successful agricultural years. With regard to livestock, cattle livestock is the main practice in the irrigated areas of Mateur. Animal resources are estimated for the year 2012 of around 45,627 head of sheep and 7,789 head of cattle [19]. $\mathrm{NO}_{3}$ fluxes from farm discharges are estimated to be about $120 \mathrm{~kg} / \mathrm{ha} /$ year [20].

2.4. Sampling and Analytical Methods. Groundwater samples were obtained from monitoring wells in the alluvial aquifers. A total of 70 samples were collected in wet and dry seasons in order to capture seasonal variability in water quality.

The piezometric level, $\mathrm{pH}$, electrical conductivity (EC), dissolved oxygen, and temperature were measured in situ. Samples were kept at $4^{\circ} \mathrm{C}$ for their subsequent chemical analyses. Afterwards, the samples were filtered through a $0.45 \mu \mathrm{m}$ Millipore filter. Chloride was determined by standard $\mathrm{AgNO}_{3}$ [21]. Sulfate $\left(\mathrm{SO}_{4}{ }^{2-}\right)$ content was measured by the gravimetric method using $\mathrm{BaCl}_{2}$. Sodium $\left(\mathrm{Na}^{+}\right)$and potassium $\left(\mathrm{K}^{+}\right)$were measured by flame photometry, and calcium $\left(\mathrm{Ca}^{2+}\right)$ and magnesium $\left(\mathrm{Mg}^{2+}\right)$ were measured with atomic absorption. Alkalinity was determined by titration with $\mathrm{HCl}$.

The quality of chemical analysis was checked by making an ionic mass balance, accepting an error rate lower than $5 \%$. Nitrate, nitrite, ammonium, and ortho-P were analyzed by colorimetric methods described by Rodier [21], using sodium salicylate, diazotization, blue of indophenol, and phosphomolybdate methods, respectively. The obtained results were applied to statistical study using Andad software [22]. Statistical summaries of the parameters analyzed for this study are presented in Table 2. Data were made available in a format that is accessible via GIS. Surfer 8 was used to generate different spatial distribution maps of various chemical constituents in the study area. Water Quality Index (WQI), sodium adsorption ratio (SAR), sodium percentage $(\% \mathrm{Na})$, and permeability index (PI) were used to evaluate the suitability of groundwater for irrigation and drinking purposes.

\section{Results and Discussion}

\subsection{Mateur Groundwater Geochemistry}

3.1.1. $\mathrm{pH}$ and $\mathrm{T}^{\circ} \mathrm{C}$. The $\mathrm{pH}$ values of Mateur alluvial aquifer water range from 7.18 to 8.39 during the wet season and between 7.02 and 8.11 throughout the dry season.

The spatial and temporal variations of $\mathrm{pH}$ are controlled by the quality and the infiltration rate of recharge water, the replenishing water rate and water-rock interaction in the aquifer. These $\mathrm{pH}$ values are all in the desirable limits set by the World Health Organization (WHO) [23].

The temperature values of groundwater varied from $18.9^{\circ} \mathrm{C}$ to $25.6^{\circ} \mathrm{C}$ during the wet season and from $18.2^{\circ} \mathrm{C}$ to $26.7^{\circ} \mathrm{C}$ during the dry season. The highest temperature values, for the same well or borehole, are recorded during dry season. The spatial variation of temperature is a function of the recharged water and of the infiltration transfer time, which in turn both depend on porosity, lithology, and 


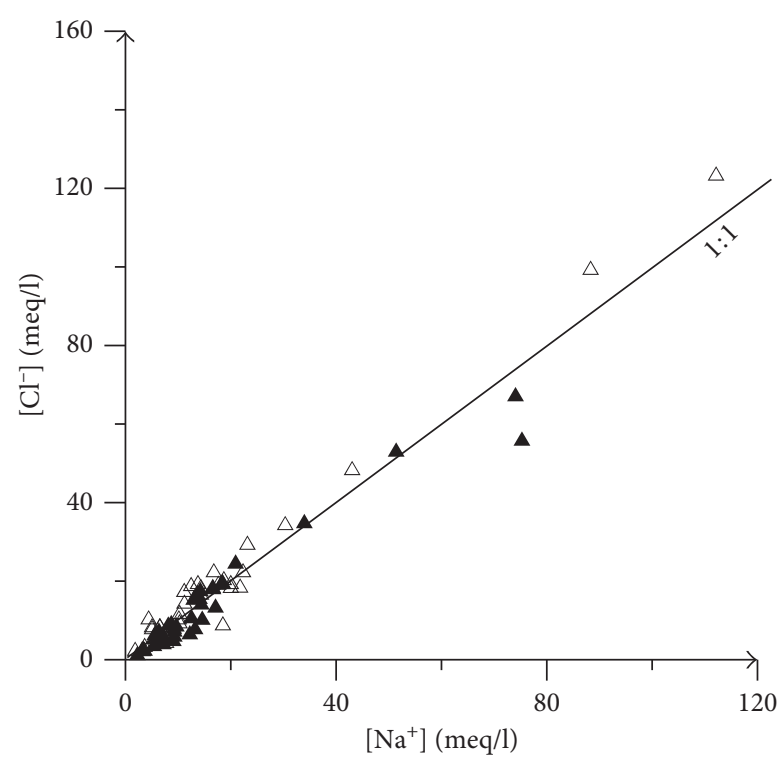

A Wet season $\triangle$ Dry season

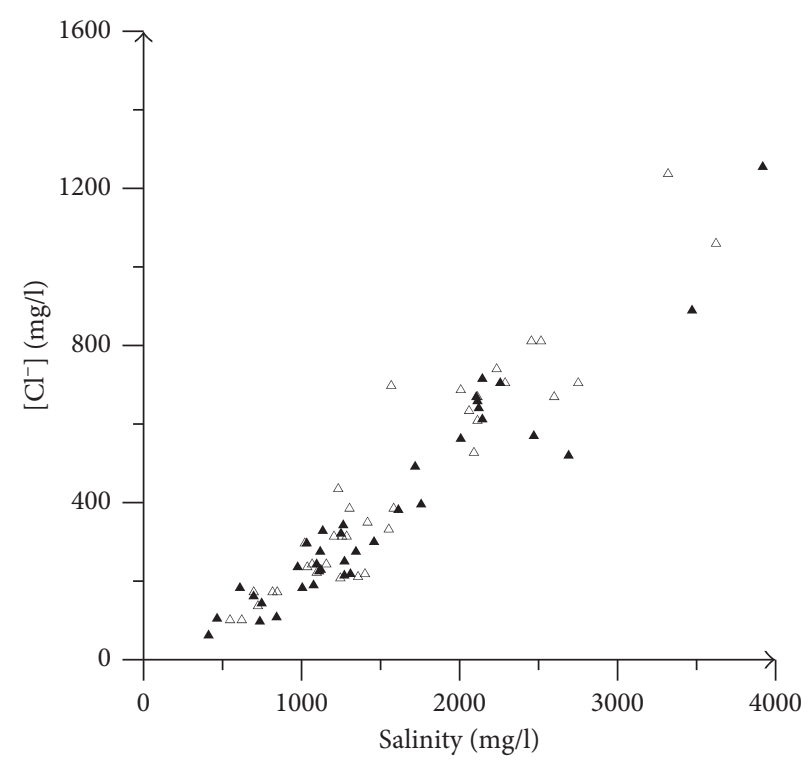

$\Delta$ Wet season

$\triangle$ Dry season

(a)

(b)

Figure 6: Bivariate pot of (a) $\mathrm{Na}^{+}$versus $\mathrm{Cl}^{-}$and (b) salinity versus $\mathrm{Cl}^{-}$.

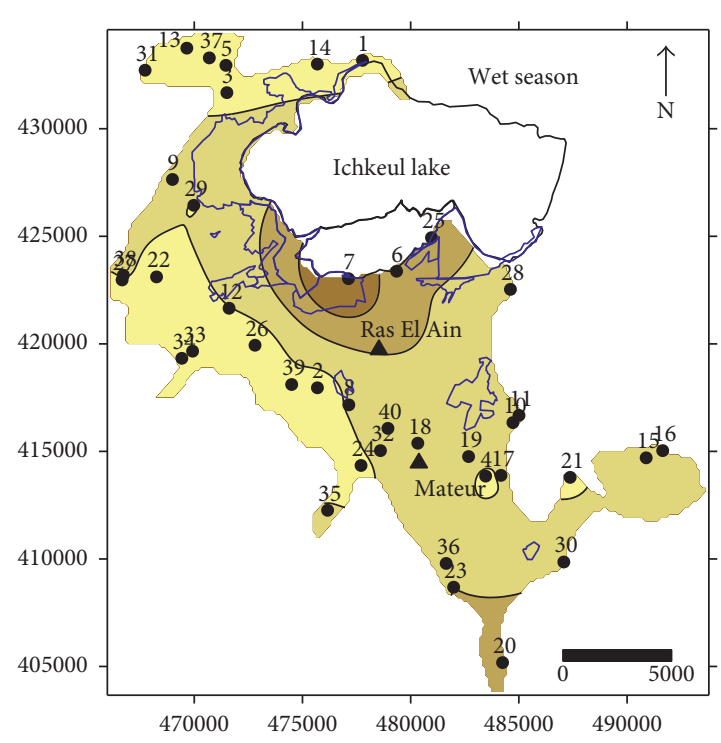

(a)

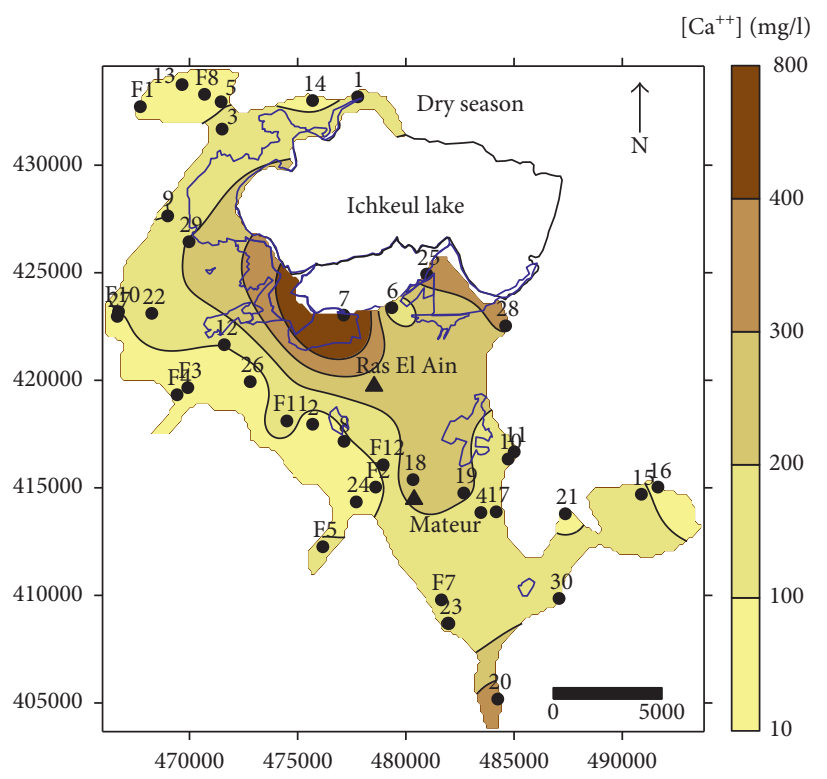

(b)

FIgURE 7: Spatial distribution maps of calcium $\left(\mathrm{Ca}^{++}\right)$: (a) wet season and (b) dry season.

thickness of the unsaturated zone. For the same sampling period, the spatial variation is marked by a decrease as the depth increases.

3.1.2. Salinity, Sodium, and Chloride. Water salinity of the Mateur aquifer varied from 0.1 to $4.5 \mathrm{~g} / \mathrm{L}$ during the wet season and from 0.1 to $8.4 \mathrm{~g} / \mathrm{L}$ throughout the dry season. The highest values were recorded during the dry season
(October), whereas the lowest values were recorded during the wet season (April). The spatial distribution maps of salinity (Figures 5(a) and 5(b)) show that the lowest values are recorded both during the wet and the dry season in the northwest and southwest parts of the aquifer. These parts correspond to the natural recharge area (dilution effect) with an increasing trend of salinity values in the water flow direction. The high salinity levels are related to the infiltration of salty water from Ichkeul marshes and of salty soil leachate 


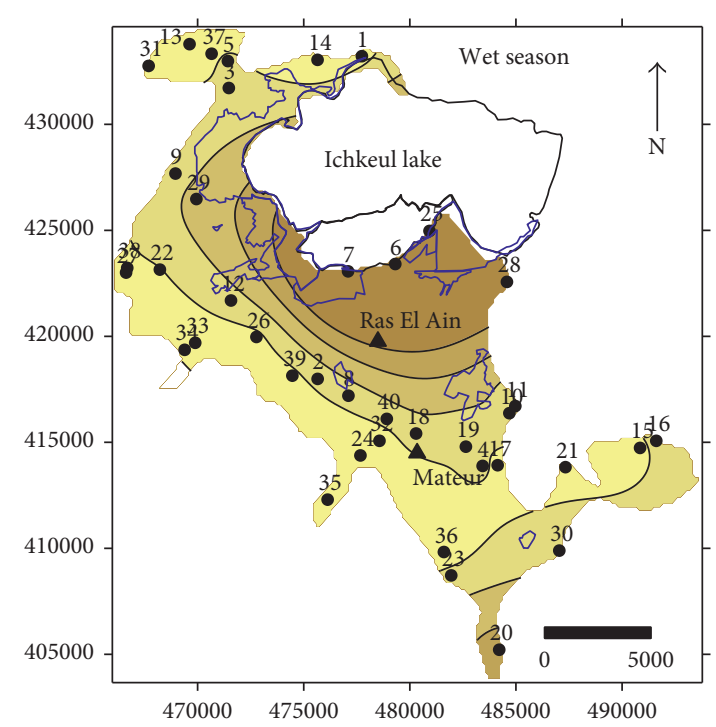

(a)

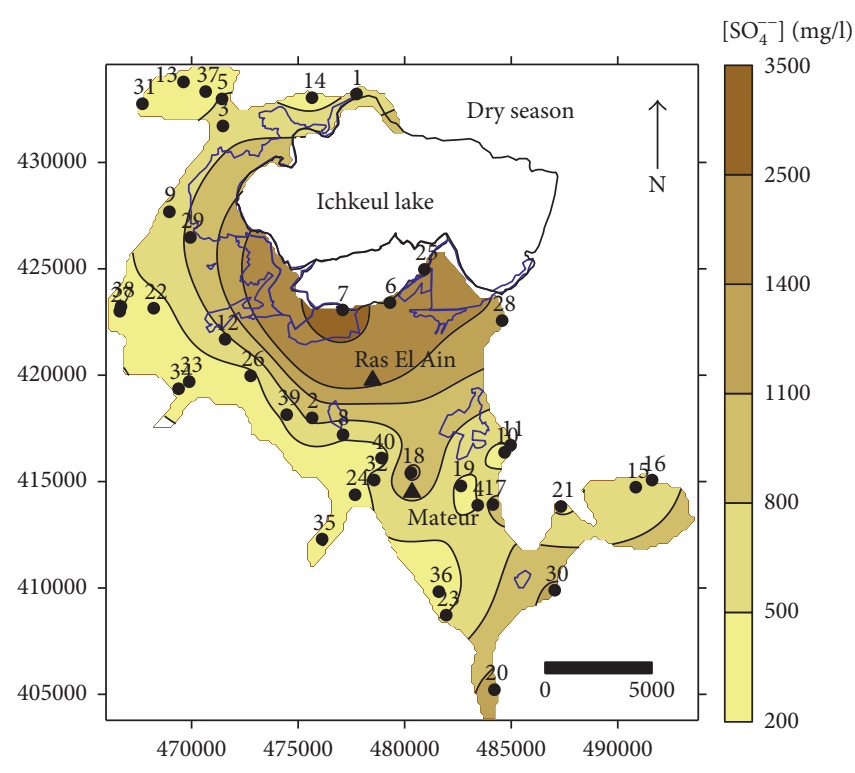

(b)

Figure 8: Spatial distribution maps of sulfate $\left(\mathrm{SO}_{4}^{--}\right)$: (a) wet season and (b) dry season.

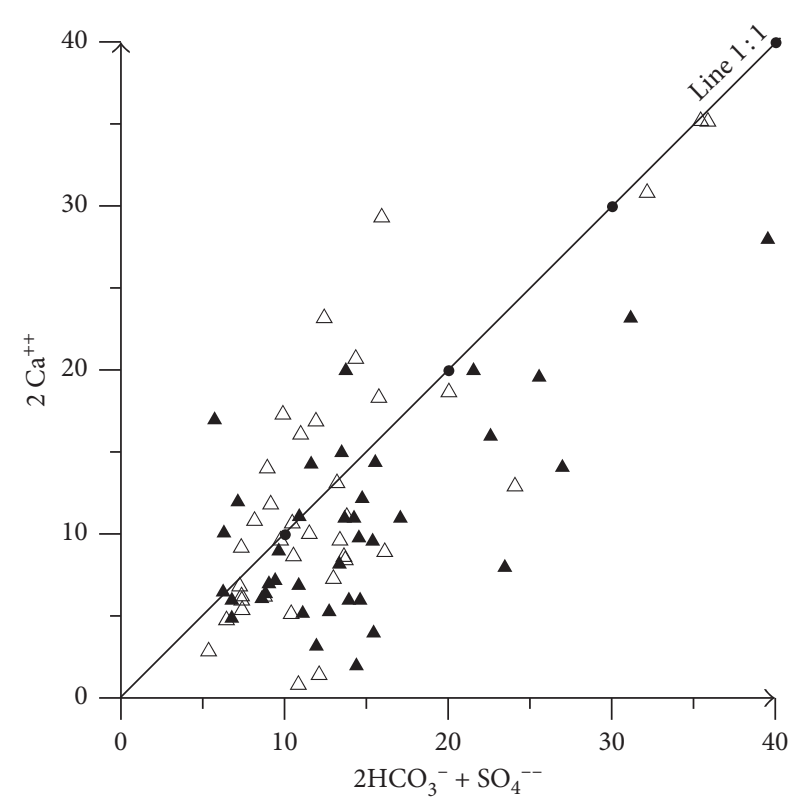

A Wet season

$\triangle$ Dry season

FIGURE 9: Geochemical relationship of $\left(2 \mathrm{HCO}_{3}+\mathrm{SO}_{4}\right)$ versus $2 \mathrm{Ca}$.

located south of Ichkeul. The main factors contributing to the groundwater salinity are dilution or evaporation, the thickness and the nature of sediments in the vadose zone, and the salty water intrusion around Ichkeul lake [11].

The concentration of chloride varied from 67 to $2406 \mathrm{mg} / \mathrm{L}$ during the wet season and from 49 to $4402 \mathrm{mg} / \mathrm{L}$ throughout the dry season. Sodium contents ranged between 49 and $1728 \mathrm{mg} / \mathrm{L}$ during wet season and between 39 and $2576 \mathrm{mg} / \mathrm{L}$ during dry season. Concentrations of chlorides and sodium show little seasonal variation. A slight decrease, more

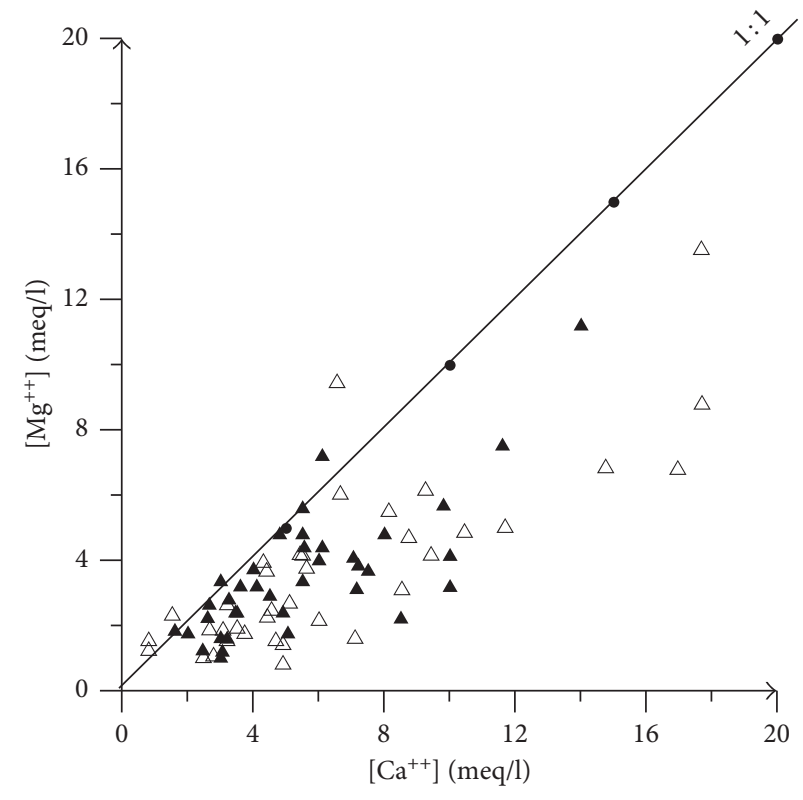

$\Delta$ Wet season

$\triangle$ Dry season

Figure 10: Bivariate pot of $\mathrm{Ca}^{2+}$ versus $\mathrm{Mg}^{2+}$.

important in the most mineralized waters, can be explained by the dilution caused by rainwater infiltration during the wet season (April), whereas evaporation contributes to ion concentration increase throughout the dry season.

$\mathrm{Cl}$ shows a strong positive correlation with $\mathrm{Na}$ (Figure 6(a)) and with salinity (Figure 6(b)), indicating that these ions seem to be dominant in the groundwater mineralization process and have the same origin: the dissolution of halite occurring in saline surface deposits and marshes around the Ichkeul lake and around salty soils. 


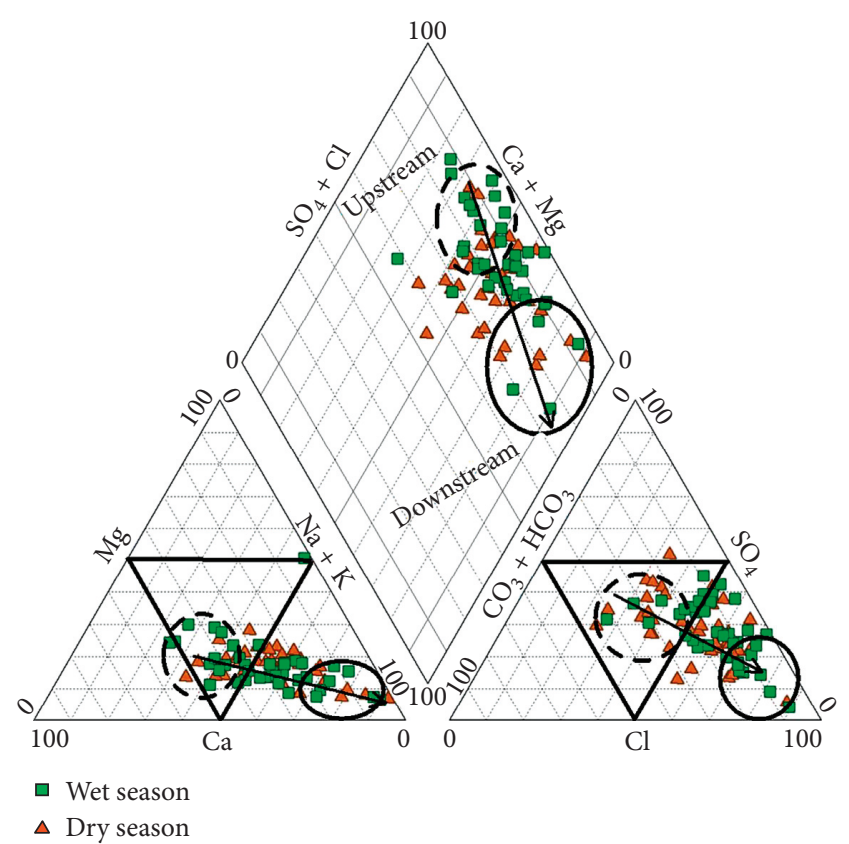

Figure 11: Piper diagram.

3.1.3. $\mathrm{Ca}^{2+}, \mathrm{Mg}^{2+}, \mathrm{HCO}_{3}^{-}$, and $\mathrm{SO}_{4}{ }^{2-}$. The spatial distribution maps of $\mathrm{Ca}^{2+}$ levels show that the highest values characterize the northeastern and the outflow parts of the aquifer (Figures $7(\mathrm{a})$ and $7(\mathrm{~b})$ ). An increasing trend with the flow direction is registered, especially during the wet season. The spatial distribution maps of sulfate contents (Figures 8(a) and $8(\mathrm{~b})$ ) show that higher sulfate values characterize the northeastern and the outflow parts of the aquifer.

A good positive correlation of $\mathrm{Ca}^{2+}$ versus $\mathrm{HCO}_{3}{ }^{-}$and $\mathrm{SO}_{4}{ }^{2-}$ (Figure 9) shows that the calcium originates, in addition to the dissolution of the calcite, from the dissolution of gypsum (R1 and R2), where the dissolution of one mole of calcite and one mole of gypsum was put into solution of two moles of $\mathrm{Ca}^{++}$, one mole of $\mathrm{SO}_{4}{ }^{2-}$, and two moles of $\mathrm{HCO}_{3}{ }^{-}$:

$$
\begin{aligned}
\mathrm{CaCO}_{3}+\mathrm{H}_{2} \mathrm{O}+\mathrm{CO}_{2}(\mathrm{~g}) \longrightarrow \mathrm{Ca}_{2}{ }^{+}+2 \mathrm{HCO}_{3}{ }^{-} \\
\mathrm{CaSO}_{4} \cdot 2 \mathrm{H}_{2} \mathrm{O} \longrightarrow \mathrm{Ca}_{2}{ }^{+}+\mathrm{SO}_{4}{ }^{2-}+2 \mathrm{H}_{2} \mathrm{O}
\end{aligned}
$$

Magnesium contents in Mateur aquifer ranged from 10 to $290 \mathrm{mg} / \mathrm{L}$ during the wet season and from 11 to $170 \mathrm{mg} / \mathrm{L}$ during the dry season. The lowest values are recorded throughout the wet season, while the highest values are recorded throughout the dry season.

A relationship of $\mathrm{Ca}$ versus $\mathrm{Mg}$ shows a positive correlation $\left(R^{2}=0.59\right)$ (Figure 10$)$, indicating the common origin and the similar geochemical behavior of these ions, which could be derived from the dissolution of magnesium calcite $\mathrm{Ca}_{1-x} \mathrm{Mg}_{x} \mathrm{CO}_{3}$.

3.1.4. Chemical Water Types. The Piper diagram (Figure 11) shows that groundwaters of the studied area are classified into two predominant facies:

(i) Mixed facies: Ca-Na-SO $\mathrm{S}_{4}-\mathrm{Cl}$ and $\mathrm{Ca}-\mathrm{Na}-\mathrm{HCO}_{3}-\mathrm{Cl}$

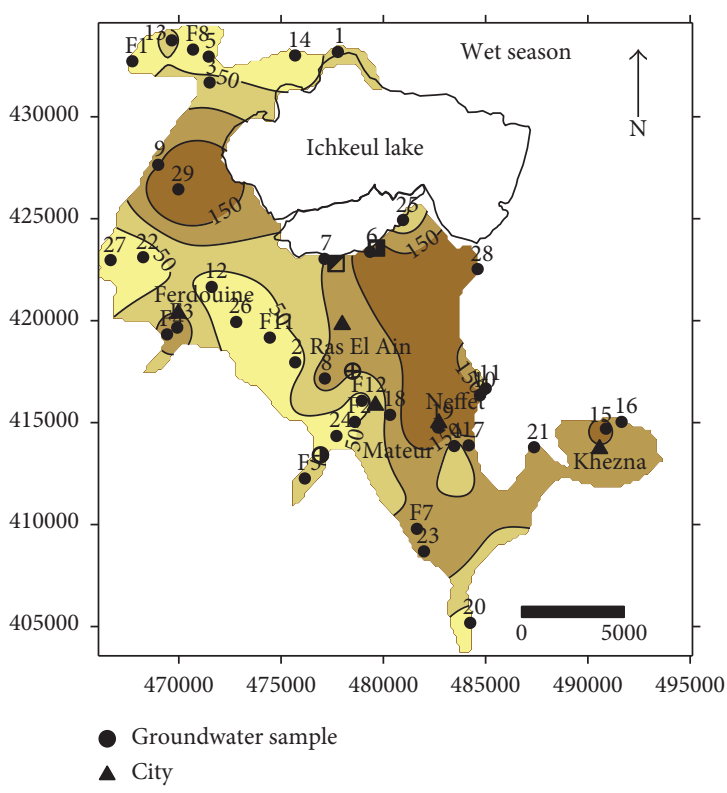

(a)

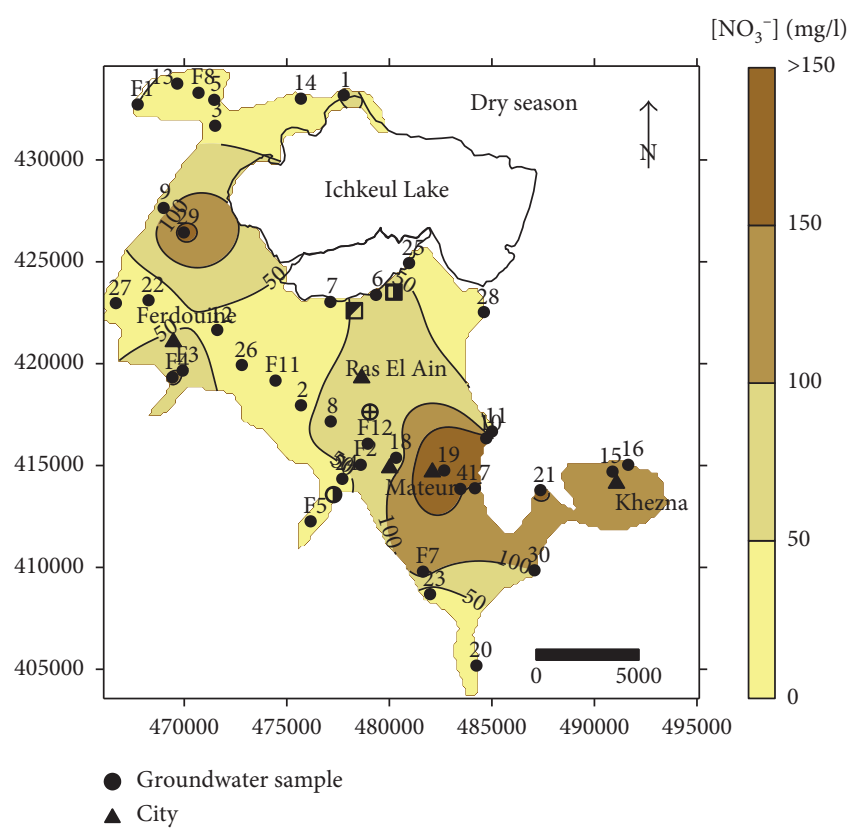

(b)

Figure 12: Spatial distribution maps of nitrate $\left(\mathrm{NO}_{3}{ }^{-}\right)$: (a) wet season and (b) dry season.

(ii) $\mathrm{Na}-\mathrm{Cl}$ facies: they characterize discharge zone and are well influenced by the leaching of salty deposits.

3.1.5. $\mathrm{NO}_{3}{ }^{-}, \mathrm{NO}_{2}{ }^{-}, \mathrm{NH}_{4}{ }^{+}$, and $\mathrm{O}_{2}$. To assess the possible anthropogenic effects on groundwater quality, water samples were classified into three groups based on the $\mathrm{NO}_{3}$ concentration during the study period as (a) below $50 \mathrm{mg} / \mathrm{L}$, (b) $50-150 \mathrm{mg} / \mathrm{L}, \mathrm{s}$ and (c) above $150 \mathrm{mg} / \mathrm{L}$. Figures 12 (a) and 12(b) illustrate a complex spatial pattern of nitrate within the aquifer. Nitrate has a WHO (World Health organization) guideline value of $50 \mathrm{mg} / \mathrm{L}$ and exceeded this 


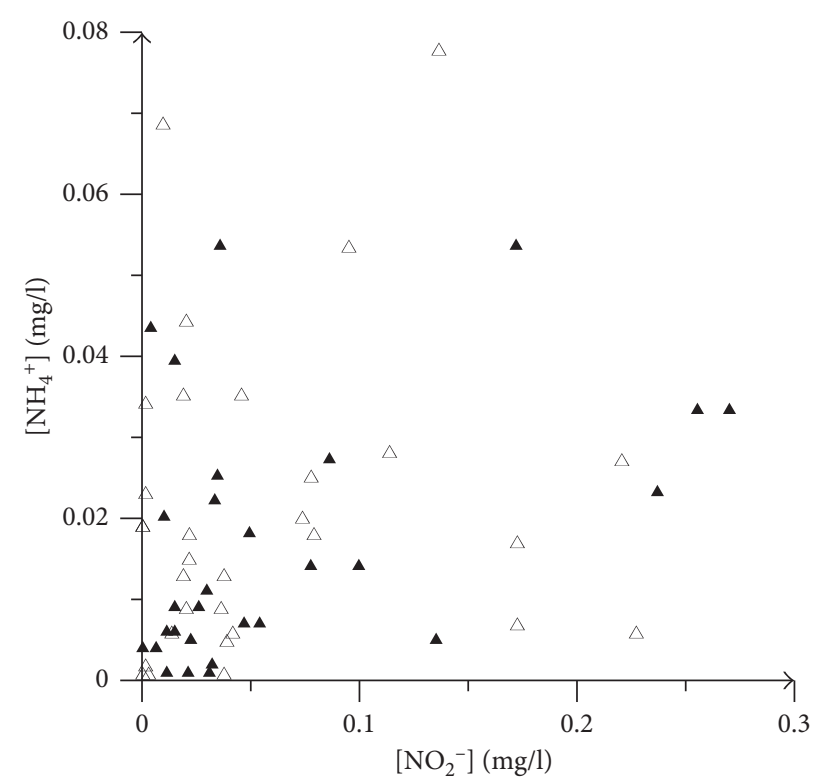

A Wet season

$\triangle$ Dry season

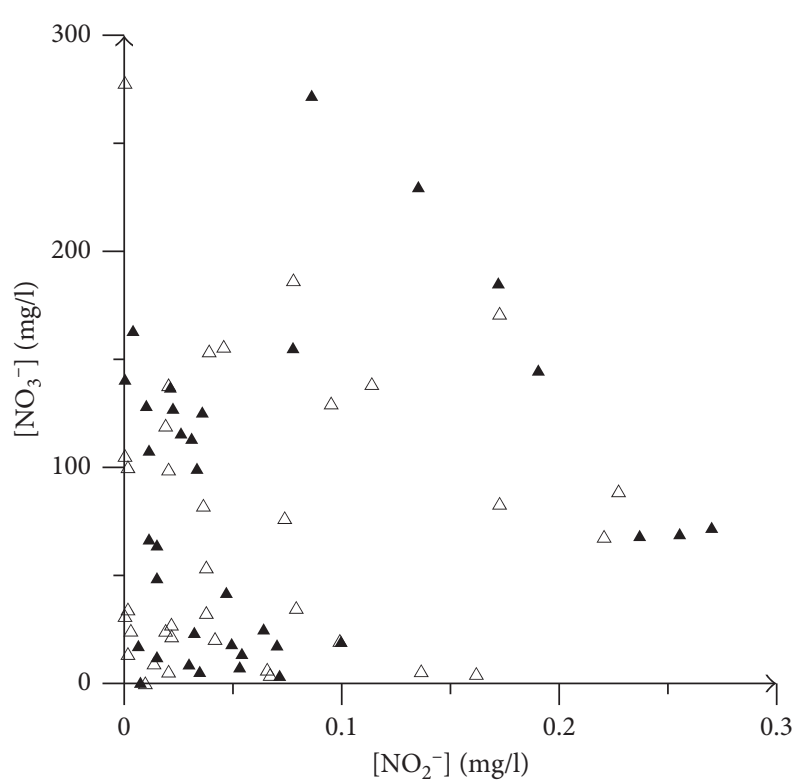

$\Delta$ Wet season

$\triangle$ Dry season

(a)

(b)

Figure 13: Bivariate pot of $\mathrm{NO}_{2}^{-}$versus $\mathrm{NH}_{4}{ }^{+}$(a) and $\mathrm{NO}_{3}{ }^{-}$(b).

concentration in $48 \%$ and $32 \%$ of samples in wet and dry seasons, respectively. The highest values were $485 \mathrm{mg} / \mathrm{L}$ and $336 \mathrm{mg} / \mathrm{L}$ during wet and dry seasons, respectively. High concentrations of nitrate are recovered in the northwestern and central part of the aquifer. Areas where nitrate concentrations are lower than $50 \mathrm{mg} / \mathrm{L}$ are located in the western part of the aquifer, which corresponds to the natural recharge zone. Considering the temporal pattern, a similar distribution pattern was observed in the dry and the wet seasons, but the magnitude of concentration was higher during the wet season. Elevated nitrate concentration was noted during the wet season due to the combination of high nitrogen fertilizer applications from January to May and the subsequent irrigation. Throughout the dry season, elevated nitrate concentration can be explained by irrigation with $\mathrm{NO}_{3}$-rich water. Indeed, fertilizer management adopted by farmers is most probably partially responsible for the observed pollution of the groundwater. This spatial distribution is also controlled by the physical, environmental, and chemical properties of the soil [24] and the particle size, lithology, and the thickness of the unsaturated zone [25]. Indeed, in spite of the position of the wells $2,14,26,22$, and 25 in the irrigated perimeter, they have lower nitrate concentration. This is explained by a clay unsaturated zone with a low permeability ranging between 86 and $433 \mathrm{~mm} /$ day. High permeabilities $(4335 \mathrm{~mm} /$ day $)$ with the correspondingly silty sand and silty unsaturated zone are also consistent with the higher groundwater nitrate concentrations in the wells 10, 15, 17, 19, and 28. Point nitrate groundwater pollution does not seem to be important in the studied area. Indeed, industrial and urban wastewater discharge into the Joumine River, which plays a groundwater drainage role to the Ichkeul Lake, cause, locally, eutrophication in its southern part.

Groundwater samples in the studied area are fairly oxygenated, so $\mathrm{NO}_{2}$ and $\mathrm{NH}_{4}{ }^{+}$concentrations were almost absent, except few wells which have dramatically higher values. Nitrite contamination is indicative of local and recently generated contamination $[26,27]$, whereas the presence of ammonium ions in groundwater is generally an indicator of groundwater pollution [28]. High nitrite values are related to wastewater leaching. The ammoniacal nitrogen may originate from the degradation of dissolved organic matter or from the infiltration of leachate water of fertilized soils.

The absence of correlation between the different inorganic nitrogen compounds $\left(\mathrm{NO}_{3}{ }^{-}, \mathrm{NO}_{2}{ }^{-}\right.$, and $\left.\mathrm{NH}_{4}{ }^{+}\right)$and $\mathrm{O}_{2}(($ Figures 13(a) and 13(b)) and (Figures 14(a)-(c))) shows that nitrates within the Mateur aquifer waters are mainly derived from the infiltration of leaching water from cultivated land in addition to a small proportion related to nitrification.

3.1.6. Ortho-P. The solubility of inorganic forms of phosphorus, mainly represented by orthophosphates, is $\mathrm{pH}$ dependent. The equilibrium reactions between orthophosphates are the following [29]:

$$
\begin{gathered}
\mathrm{H}_{3} \mathrm{PO}_{4} \leftrightharpoons \mathrm{H}_{2} \mathrm{PO}_{4}^{-}+\mathrm{H}^{+} \quad \mathrm{pK}=2.2 \\
\mathrm{H}_{2} \mathrm{PO}_{4}^{-} \leftrightharpoons \mathrm{HPO}_{4}^{--}+\mathrm{H}^{+} \quad \mathrm{pK}=7.2 \\
\mathrm{HPO}_{4}^{--} \leftrightharpoons \mathrm{PO}_{4}{ }^{3-}+\mathrm{H}^{+} \quad \mathrm{pK}=12.3
\end{gathered}
$$




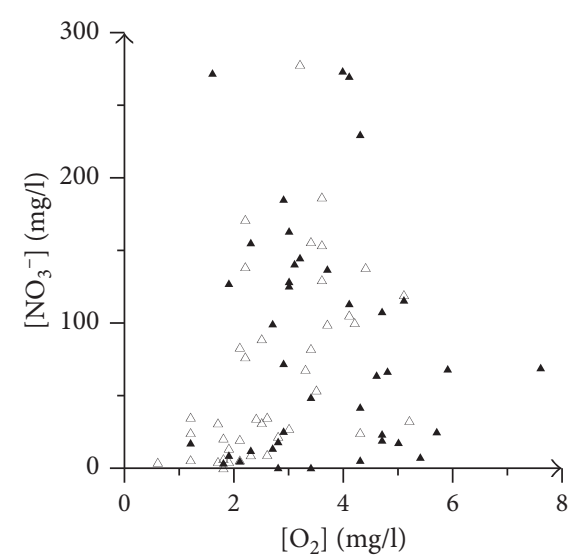

A Wet season $\triangle$ Dry season

(a)

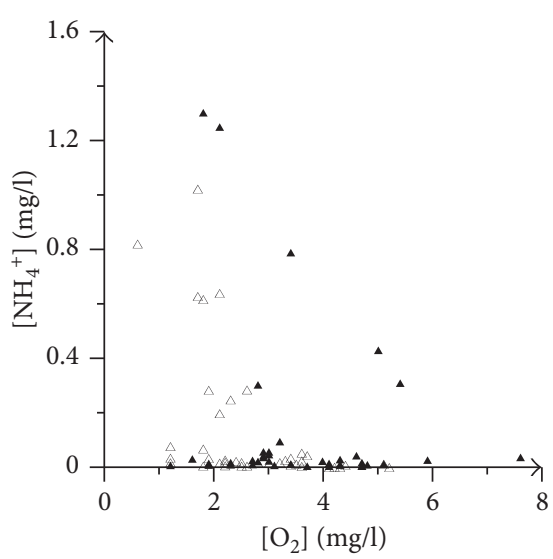

A Wet season

$\triangle$ Dry season

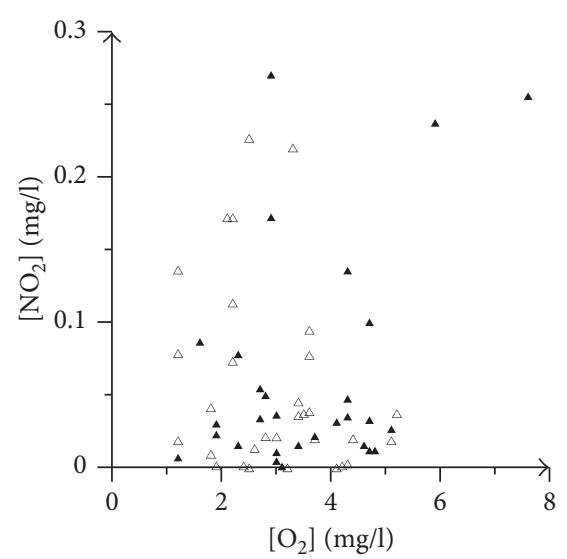

- Wet season

$\triangle$ Dry season

(b)

FIGURE 14: Bivariate pot of $\mathrm{O}_{2}$ versus $\mathrm{NO}_{3}{ }^{-}$(a) $\mathrm{NH}_{4}{ }^{+}$(b) and $\mathrm{NO}_{2}{ }^{-}$(c).

TABLE 3: Weight and relative weight of chemical parameters used for WQI computation.

\begin{tabular}{lccc}
\hline & $S_{i}$ & $w_{i}$ & $W_{i}$ \\
\hline Salinity & 1500 & 5 & 0.152 \\
Bicarbonates & & 1 & 0.030 \\
Chlorides & 400 & 5 & 0.152 \\
Sulfates & 400 & 5 & 0.152 \\
Nitrates & 50 & 5 & 0.152 \\
Calcium & 300 & 3 & 0.091 \\
Magnesium & 150 & 3 & 0.091 \\
Sodium & 200 & 4 & 0.121 \\
Potassium & & 2 & 0.061 \\
& & Total $w_{i}=33$ & Total $W_{i}=1$ \\
\hline
\end{tabular}

These reactions indicate that $\mathrm{HPO}_{4}{ }^{2-}$ is the dominant form within a $\mathrm{pH}$ range of 7.2 and 12.5. According to the $\mathrm{pH}$ values of groundwater in the study area, the dominant form of orthophosphates is $\mathrm{HPO}_{4}{ }^{2-}$ with contents between 10 and $482 \mu \mathrm{g} / \mathrm{L}$ during the wet season and between 20 and $637 \mu \mathrm{g} / \mathrm{L}$ during the dry season. The highest orthophosphate contents are recorded in the outflow parts of the aquifer and might be connected to the fertilization of agricultural land by phosphorus fertilizers (diammonium phosphate and super 45). Indeed, the repeated phosphorus fertilization increases the transfer of phosphorus to the aquifer $[30,31]$. High orthophosphate levels would be related also to the discharge of urban wastewater in Joumine River.

\subsection{Groundwater Suitability}

3.2.1. Suitability for Drinking Purposes Using Water Quality Index (WQI). Water Quality Index is one of the most effective tools to communicate information on the quality of water to the concerned citizens and policymakers. It is an important parameter for the assessment and management of groundwater. WQI is defined as a rating reflecting the composite influence of different water quality parameters [32]. By mapping the index, the areas of high and low water
TABle 4: Water Quality Index (WQI) ranges and percentage of samples during wet and dry seasons.

\begin{tabular}{lccc}
\hline $\begin{array}{l}\text { WQI } \\
\text { range }\end{array}$ & Water quality & $\begin{array}{c}\text { Wet } \\
\text { season }\end{array}$ & $\begin{array}{c}\text { Dry } \\
\text { season }\end{array}$ \\
\hline$<50$ & Excellent & 12.50 & 10 \\
$50-100$ & Good & 40 & 45 \\
$100-200$ & Poor & 35.50 & 35 \\
$200-300$ & Very poor & 5 & 2.50 \\
$>300$ & Unsuitable for domestic & 7.50 & 7.50 \\
& purposes & & \\
\hline
\end{tabular}

quality can easily be distinguished by scientists as well as by policymakers or the general public, for treatment before various uses [33].

To compute the WQI, three steps are followed [34]. In the first step, each of the 9 parameters is assigned a weight $\left(W_{i}\right)$ according to its relative importance in the overall quality of water for drinking purposes (Table 3). In the second step, the relative weight $\left(W_{i}\right)$ is computed from the following equation (6):

$$
W_{i}=\frac{w_{i}}{\sum_{i=1}^{n} w_{i}}
$$

where $w_{i}$ is the weight of each parameter and $n$ is the number of parameters.

To compute the WQI (9), the SI is first determined for each chemical parameter, which is then used to determine the WQI as in the following equation (7):

$$
\begin{aligned}
& \mathrm{SI}_{i}=W_{i} * q_{i}, \\
& q_{i}=\left(\frac{C_{i}}{S_{i}}\right) * 100,
\end{aligned}
$$

where $C_{i}$ is the concentration of each chemical parameter in each water sample in $\mathrm{mg} / \mathrm{L}$.

$S_{i}$ is a World Health Organization's standard for each of the major parameters in drinking water [23]. 


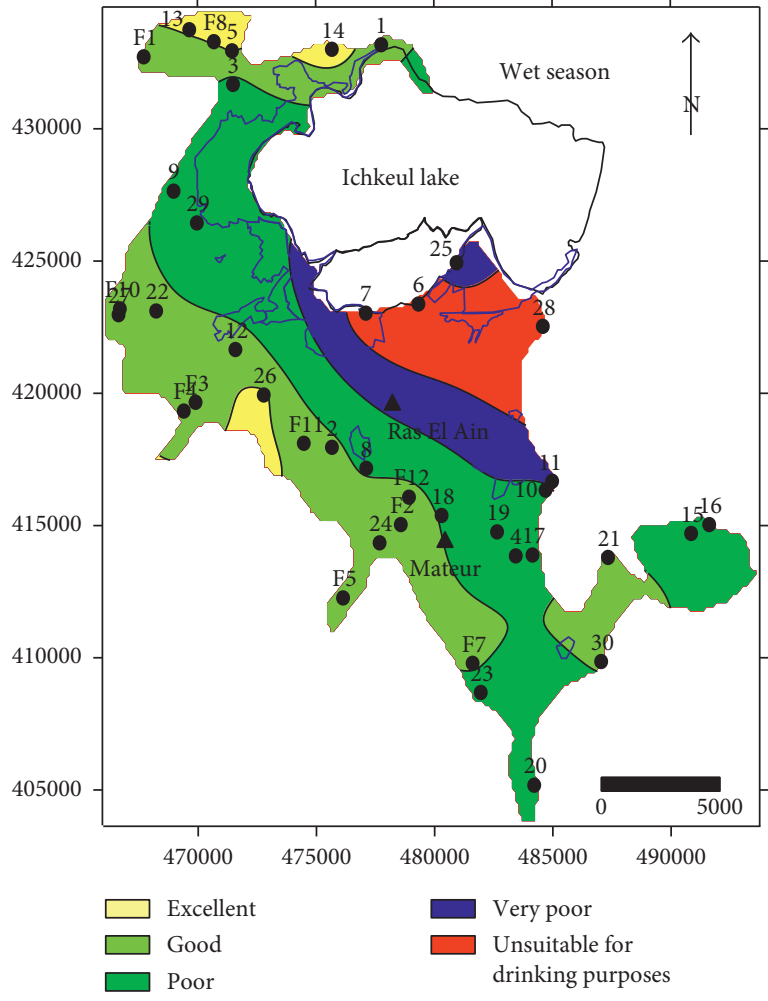

(a)

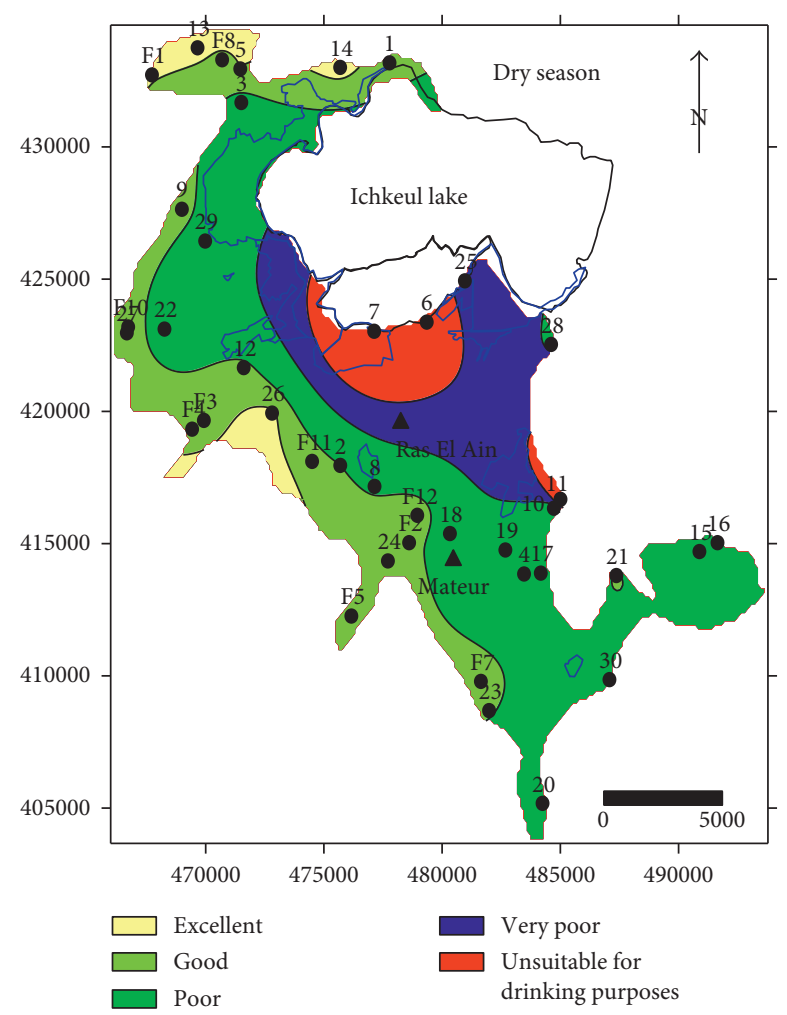

(b)

FIgURE 15: Spatial distribution maps of WQI.

$$
\mathrm{WQI}=\sum \mathrm{SI}_{i},
$$

where $\mathrm{SI}_{i}$ is the subindex of $i$ th parameter, $q_{i}$ is the rating based on the concentration of $i$ th parameter, and $n$ is the number of parameters.

The computed WQI values are classified into five types, from "excellent water" to "water, unsuitable for drinking" (Table 4) [32]. In the current study, a total of nine chemical parameters (salinity, $\mathrm{Na}^{+}, \mathrm{Cl}^{-}, \mathrm{Ca}^{2+}, \mathrm{Mg}^{2+}, \mathrm{SO}_{4}{ }^{2-}, \mathrm{K}^{+}$, $\mathrm{HCO}_{3}{ }^{-}$, and $\mathrm{NO}_{3}{ }^{-}$) of 40 water samples were used to calculate WQI, in order to assess the suitability of the Mateur aquifer groundwater for domestic (drinking) use. The weights assigned to the parameters ranged between 1 and 5 (Table 3 ) and were based on the health effects of these parameters. The highest weight (5) was assigned to salinity and nitrate due to their major importance in water quality assessment and the health implications of the high concentration of these chemical parameters in water $[35,36]$.

The spatial distribution of Water Quality Index (Figure 15) shows the highest quality $(12.5 \%$ and $40 \%$ of groundwater samples fell into excellent to good, resp., during both seasons). These two categories characterize the northwest and the southeast part of the aquifer, corresponding to the recharge zone. The water samples within poor quality, very poor quality, and unsuitable for drinking purposes contributed $35.5 \%, 5 \%$, and $7.5 \%$ of groundwater samples, respectively in the wet season with no remarkable difference in the dry season. Poor and very poor water qualities were found in the center and east part of the aquifer and cannot be used for drinking without any treatment and conventional disinfection, whereas water "unsuitable for drinking purposes" could only be used for aquaculture, irrigation, and industrial purposes and characterizes the outflow part of the aquifer [37].

3.2.2. Suitability for Irrigation. The long-term effect of irrigation water on physical and chemical properties of soil and crop productivity depends on the conductivity and sodium contents, dissolved inorganic carbon and alkaline earth elements ( $\mathrm{Ca}$ and $\mathrm{Mg}$ ) of irrigation water, and initial physical properties of soil [36].

In order to assess the irrigation suitability of Mateur aquifer groundwaters, the following parameters were used: sodium percentage $(\% \mathrm{Na})$, sodium adsorption ratio (SAR), and permeability index (PI).

(1) Sodium Adsorption Ratio (SAR). The sodicity hazard of water is generally described by the sodium adsorption ratio. Indeed, there is a significant relationship between SAR values of irrigation water and the extent to which sodium is adsorbed by the soil [24]. If water used for irrigation is high in sodium and low in calcium, the cation exchange complex may become saturated with sodium, which can destroy the soil structure due to the dispersion of clay particles [38]. SAR is computed from the following equation (10), where the concentrations are reported in meq/L. 


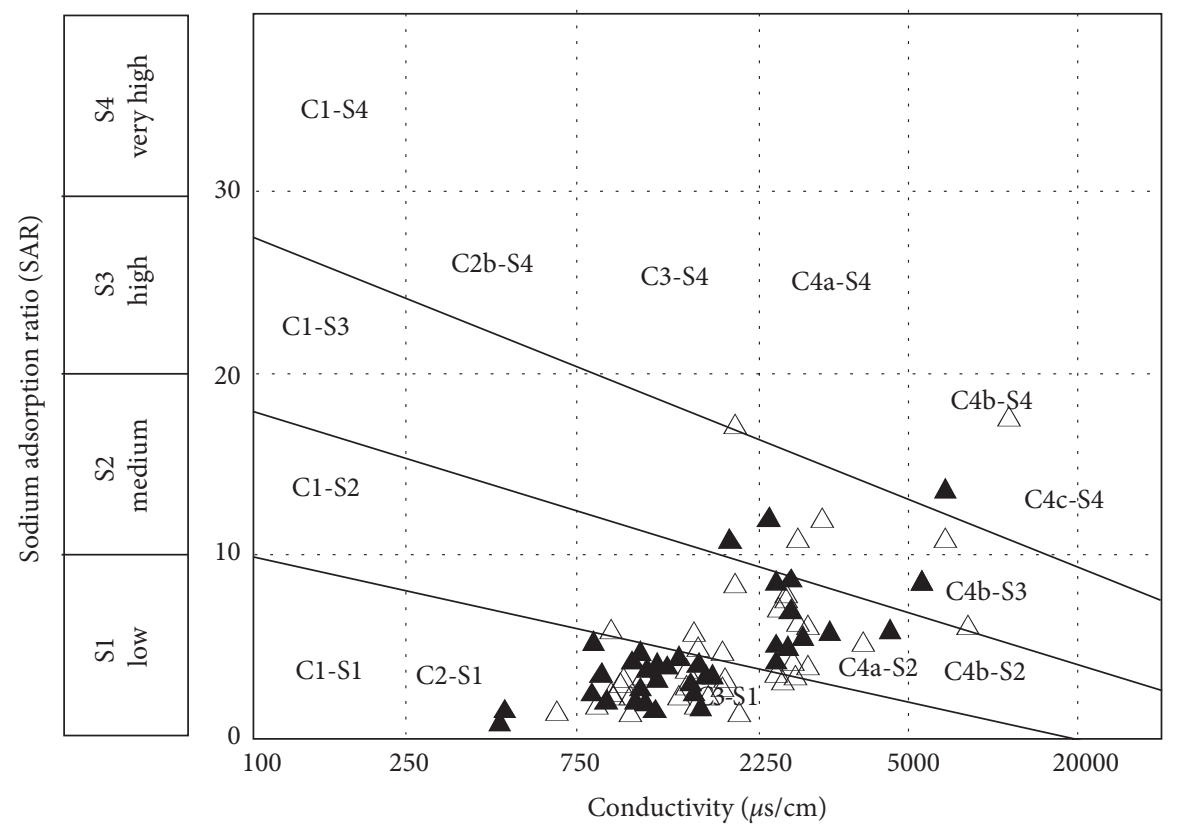

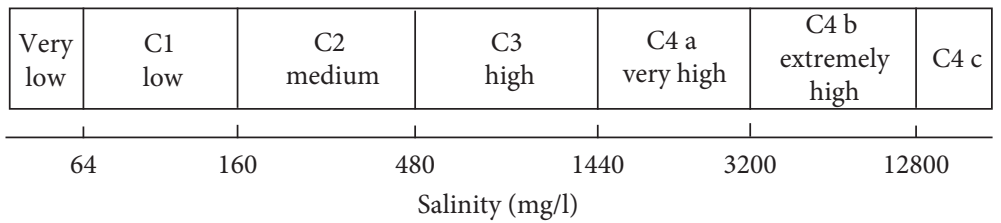

Wet season

$\triangle$ Dry season

FIGURE 16: USSR diagram for the study area.

TABLE 5: Irrigation quality of groundwater based on sodium percentage.

\begin{tabular}{lcccccccc}
\hline & $\mathrm{C} 2 \mathrm{~S} 1(\%)$ & $\mathrm{C} 3 \mathrm{~S} 1(\%)$ & $\mathrm{C} 4 \mathrm{aS} 2(\%)$ & $\mathrm{C} 4 \mathrm{bS} 2(\%)$ & $\mathrm{C} 4 \mathrm{aS} 1(\%)$ & $\mathrm{C} 4 \mathrm{bS} 4(\%)$ & $\mathrm{C} 4 \mathrm{bS} 3(\%)$ & $\mathrm{C} 3 \mathrm{~S} 4(\%)$ \\
\hline Wet season & 5 & 42 & 21 & 2 & - & 3 & - & - \\
Dry season & 3 & 36 & 18 & 3 & 12 & - & - & 3 \\
\hline
\end{tabular}

$$
\mathrm{SAR}=\frac{\mathrm{Na}}{\sqrt{(\mathrm{Ca}+\mathrm{Mg} / 2)}}
$$

The SAR values in the study area range between 4.08 and 13.9. All the sampling points on the US salinity diagram are shown in Figure 16 and summarized in Table 5. Figure 16 illustrates that the majority of water samples fall into C3S1 and C4aS2 fields during both seasons. $42 \%$ and $36 \%$ of groundwater samples fall into C3S1 during wet and dry seasons, respectively, indicating water of medium-to-high salinity and low SAR category, without risk of soil destabilization. This water falls into admissible class (C3S1) characterizing groundwater samples located in the natural recharge zone of the aquifer and can be used for irrigation of plants having a good salt tolerance, on well-drained soils or good permeability, with salinity control [39]. $23 \%$ and $21 \%$ of groundwater samples fall into C4S2 field poor class (C4S1-C4S2) in wet and dry seasons, respectively, indicating very high salinity and medium alkalinity hazards. This class is characterized by strongly mineralized water presenting important risk of soil salinization, but with medium risk of alkalization. It is found in the center and the east part of the aquifer (Figure 17). Very high salinity waters are unsuitable for irrigation with a suitable drainage. An adequate drainage with low salinity waters and plants having good salt tolerance should be selected.

(2) Percentage of Sodium (\% $\mathrm{Na}$ ). Wilcox [40] used \% $\mathrm{Na}$ and specific conductance in evaluating the suitability of groundwater for irrigation. \% $\mathrm{Na}$ is calculated using the following relation (11):

$$
\% \mathrm{Na}=\left(\frac{\mathrm{Na}}{\mathrm{Na}+\mathrm{Ca}+\mathrm{Mg}+\mathrm{K}}\right) * 100,
$$

where all the ionic concentrations are expressed in meq/L.

All groundwater samples on the Wilcox diagram are shown in Figure 18 and summarized in Table 6. Groundwater samples in the study area fall into five categories: (i) good to excellent categories, which represent $47 \%$ to $8 \%$ of 


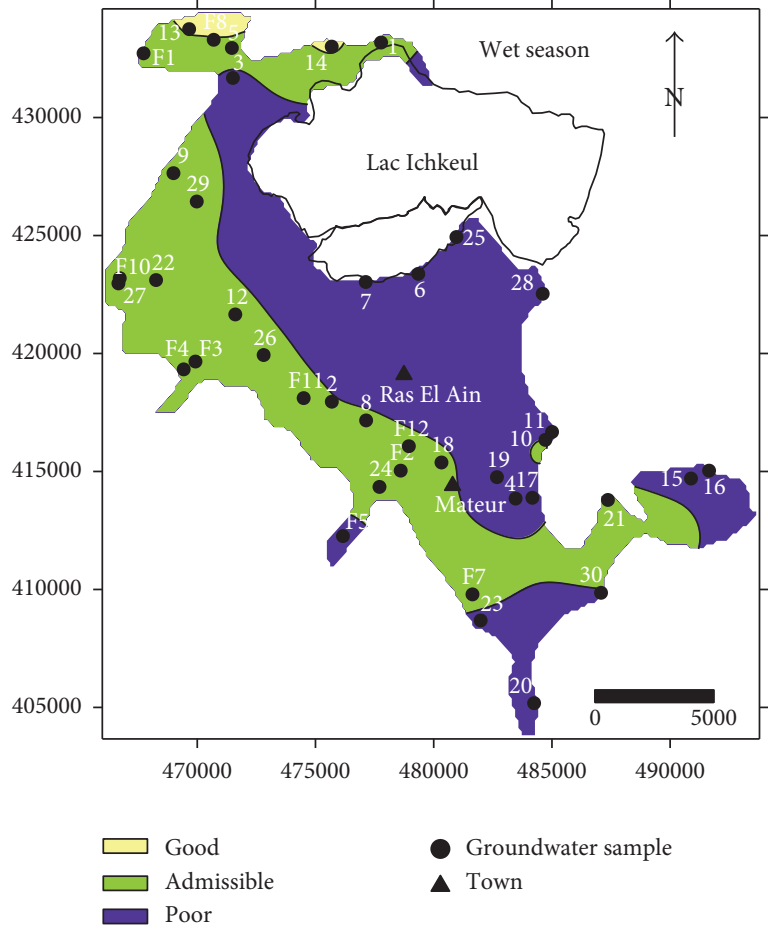

(a)

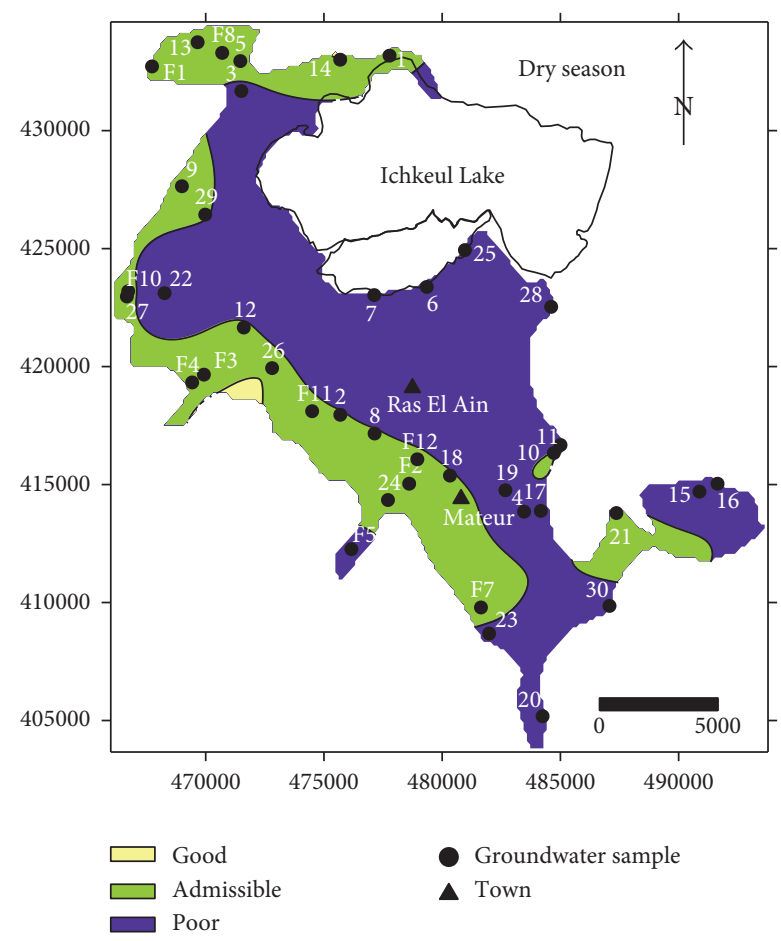

(b)

FIgURE 17: Spatial distribution maps of the irrigation suitability classes of the study area.

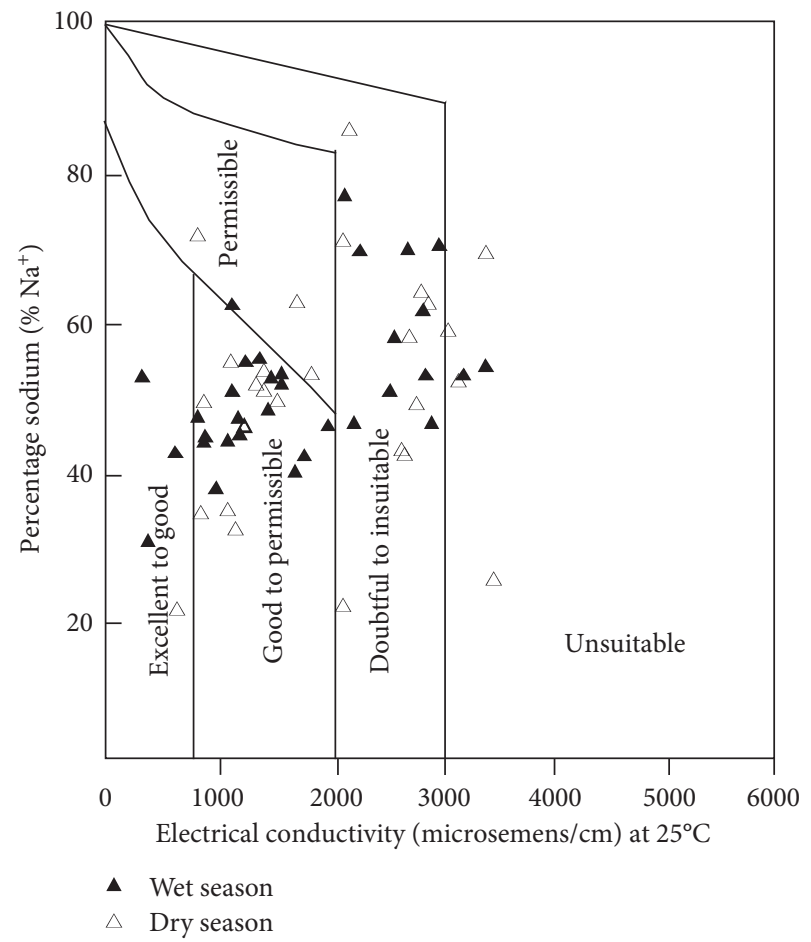

FiguRe 18: Wilcox diagram for the study area.

the groundwater samples during the wet seasonand $30 \%$ to $3 \%$ of the groundwater samples during the dry season, respectively; (ii) permissible categories, which are moderately mineralized and represent $2 \%$ of groundwater samples during the wet season and $9 \%$ throughout the dry season;
TABLE 6: Salinity and alkalinity hazards of irrigation water in US salinity diagram.

\begin{tabular}{lccccc}
\hline & $\begin{array}{c}\text { Excellent } \\
(\%)\end{array}$ & $\begin{array}{c}\text { Good } \\
(\%)\end{array}$ & $\begin{array}{c}\text { Permissible } \\
(\%)\end{array}$ & $\begin{array}{c}\text { Doubtful } \\
(\%)\end{array}$ & $\begin{array}{c}\text { Unsuitable } \\
(\%)\end{array}$ \\
\hline $\begin{array}{l}\text { Wet } \\
\text { season }\end{array}$ & 8 & 47 & 2 & 26 & 10 \\
$\begin{array}{l}\text { Dry } \\
\text { season }\end{array}$ & 3 & 30 & 9 & 21 & 18 \\
\hline
\end{tabular}

and (iii) from poor to very poor quality water, which are the most mineralized, with the highest percentage of sodium. These waters represent $26 \%$ to $10 \%$ of all water during the wet season and $21 \%$ to $18 \%$ during the dry season and are located mainly in the eastern part of the web and in the discharge area, in the marshes of Ichkeul.

It is noteworthy that when the sodium content is high in irrigation water, this element tends to replace the $\mathrm{Ca}$ and $\mathrm{Mg}$ ions in the interlayer space of soil clays, reducing its permeability, and thus, causing poor internal drainage $[36,41]$.

(3) Permeability Index. The permeability index is an important factor, which influences the quality of irrigation water in relation to the soil for development in agriculture [42].

The permeability index (PI) of a water sample is computed from the following equation (12), where concentrations are in $\mathrm{meq} / \mathrm{L}$.

$$
\mathrm{PI}=\left(\frac{\mathrm{Na}+\sqrt{\mathrm{HCO}_{3}}}{(\mathrm{Na}+\mathrm{Ca}+\mathrm{Mg})}\right) * 100 .
$$




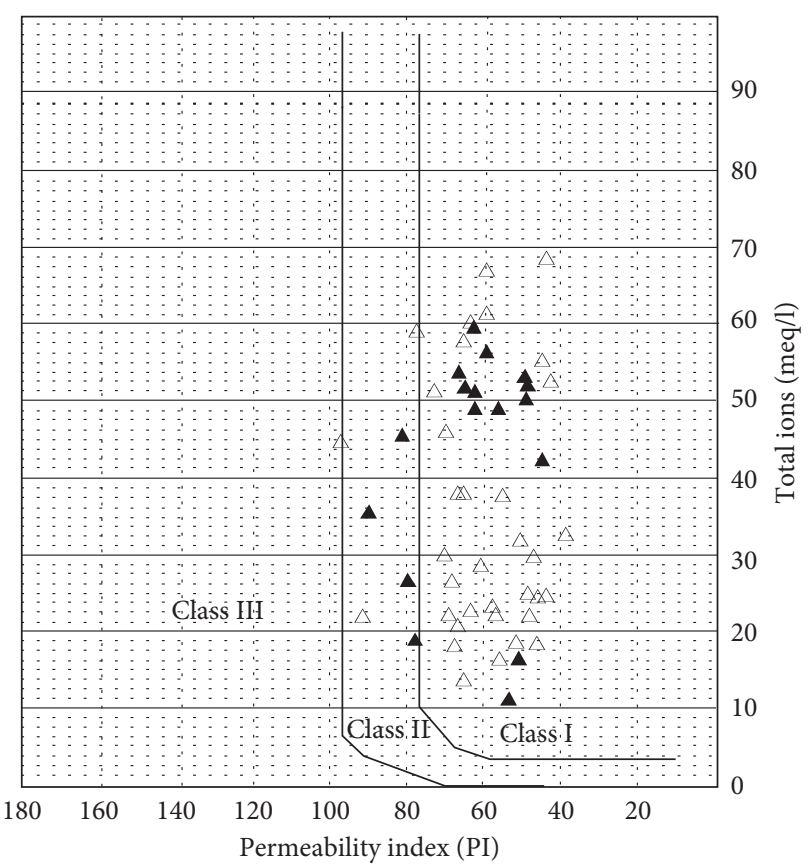

A Wet season

$\triangle$ Dry season

Figure 19: A Doneen's chart for the study area.

Permeability indices were plotted with the total ionic content of the groundwater samples on a Doneen's chart [42], which represent three different classes: CI with the best water type for irrigation, CII water generally acceptable, and CIII waters unacceptable [44].

In the study area, the PI ranged from 52.44 to 64.09 with an average of 56.13, Figure 19 shows that all the samples fall within the CI best water type for irrigation purposes.

\section{Conclusions}

The objective of this study is to assess the seasonal variation in the physicochemical characteristics of water supply wells in the Mateur plain, Northern Tunisia. The WQI was applied to investigate the seasonal changes and the factors influencing groundwater hydrochemistry and hence its suitability for irrigation and domestic purposes. The investigation results suggest the following: (i) The highest quality was found, during both the wet and dry season, in the northwest and southeast part of the aquifer, corresponding to the recharge zone where $12.5 \%$ and $40 \%$ of groundwater samples fell into excellent to good categories, respectively. Toward the flow direction, groundwaters become poor to very poor and need treatment before consumption. (ii) Most of the groundwater samples fell in doubtful to unsuitable categories, characterizing the eastern part of the aquifer and the outflow part, around the Ichkeul marshes. These waters with high to very high salinity are unsuitable for irrigation purposes in ordinary conditions, an adequate drainage with low salinity waters and plants having good salt tolerance should be selected. (iii) The little seasonal change of groundwaters' quality of Mateur aquifer is mainly related to dilution in the wet season, evaporation throughout the dry season, and agricultural activities.

\section{Data Availability}

The data used to support the findings of this study are available from the corresponding author upon request.

\section{Conflicts of Interest}

The authors declare that they have no conflicts of interest.

\section{Supplementary Materials}

A table showing the subindex of $i$ th parameter $\left(\mathrm{SI}_{i}\right)$ values during wet and dry seasons was added as supplementary material. (Supplementary Materials)

\section{References}

[1] R. T. Nickson, J. M. McArthur, B. Shrestha, T. O. Kyaw-Nyint, and D. Lowry, "Arsenic and other drinking water quality issues, Muzaffargarh District, Pakistan," Applied Geochemistry, vol. 20, no. 1, pp. 55-68, 2005.

[2] S. R. Carpenter, N. F. Caraco, D. L. Correll, R. W. Howarth, A. N. Sharpley, and V. H. Smith, "Non-point pollution of surface waters with phosphorus and nitrogen," Ecological Applications, vol. 8, no. 3, pp. 559-568, 1998.

[3] J. Chen, F. Wang, X. Xia, and L. Zhang, "Major element chemistry of the Changjiang (Yangtze River)," Chemical Geology, vol. 187, no. 3-4, pp. 231-255, 2002.

[4] M. Milovanovic, "Water quality assessment and determination of pollution sources along the Axios/Vardar River, Southeastern Europe," Desalination, vol. 213, no. 1-3, pp. 159-173, 2007.

[5] M. Vasanthaviga, K. Srinivasamoorthy, R. Vijayaragavan et al., "Application of water quality index for groundwater quality assessment: Thirumanimuttar sub-basin, Tamilnadu, India," Environmental Monitoring and Assessment, vol. 171, no. 1-4, pp. 595-609, 2010.

[6] W. R. Kelly, "Heterogeneities in ground-water geochemistry in a sand aquifer beneath an irrigated field," Journal of $\mathrm{Hy}$ drology, vol. 198, no. 1-4, pp. 154-176, 1997.

[7] T. Y. Stigter, S. P. J. van Ooijen, V. E. A. Post, C. A. J. Appello, and A. M. M. Carvalho Dill, "A hydrogeological and hydrochemical explanation of the groundwater composition under irrigated land in a Mediterranean environment, Algarve, Portugal," Journal of Hydrology, vol. 208, no. 3-4, pp. 262-279, 1998.

[8] E. E. Cey, D. L. Rudolf, R. Aravena, and G. Parkin, "Role of the riparian zone in controlling the distribution and fate of agricultural nitrogen near a small stream in southern Ontario," Journal of Contaminant Hydrology, vol. 37, no. 1-2, pp. 45-67, 1999.

[9] T. Peterson, G. Folland, W. Gruza et al., Report of the Activities of the Working Group on Climate Change Detection and Related Rapporteurs 1998-2001, National Oceanography Centre, Southampton, UK, 2001.

[10] M. Massoud, M. D. Scrimshaw, and J. N. Lester, "Qualitative assessment of the effectiveness of the mediterranean action plan: wastewater management in the Mediterranean Region," Ocean and Coastal Management, vol. 46, no. 9-10, pp. 875-899, 2003.

[11] B. Tlili-Zrelli, M. Gueddari, R. Bouhlila, and M. N. Oueslati, "Groundwater hydrogeochemistry of Mateur alluvial aquifer 
(Northern Tunisia)," Journal of Hydrogeology \& Hydrologic Engineering, vol. 5, no. 1, 2016.

[12] DGRE, Annuaires d'Exploitation des Nappes Profondes, Direction Générale des Ressources en Eaux, Tunis, Tunisia, 2010.

[13] DGRE, Annuaires d'Exploitation des Nappes Phréatiques, Direction Générale des Ressources en Eaux, Tunis, Tunisia, 2005.

[14] F. Melki, T. Zouaghi, S. Harraba, A. Z. Sainez, M. Bédir, and F. Zargouni, "Structuring and evolution of Neogene transcurrent basins in the Tellian foreland domain, north-eastern Tunisia," Journal of Geodynamics, vol. 52, no. 1, pp. 57-69, 2011.

[15] M. Ennabli, "Etude hydrogéologique des aquiferes du Nord-Est de la Tunisie pour une gestion intégrée des ressources en eau," Thèse de Doctorat d'Etat, Université de Paris, Nice, France, 1980.

[16] M. Ennabli, "Contribution à l'étude Hydrogélogique de la Plaine de Mateur," Thèse de. 3ème Cycle, Faculté des Sciences de Paris, Tunis, Tunisia, 1967.

[17] A. Mori, Etude Pédologique du Périmètre de Mateur Oued Melah et Oued Sejnane, OROSTOM, Service du sol Ministère de l'Agriculture et des Ressources en eau, Dubai, UAE, 1962.

[18] CRDA, Commissariat Régional de Développement Agricole Rpp. Int, 2007.

[19] CRDR, Commissariat Régional de Développement Régional: Gouvernorat de Bizerte en Chiffres, 2012, ISSN 1737-8790.

[20] A. Jendoubi and R. Bouhlila, "Modelling of nitrate transport in the Mateur aquifer (Tunisia)," in Proceedings of the Conference on Impact of Human Activity on Groundwater Dynamics, Maastricht, Netherlands, July 2001.

[21] J. Rodier, L'Analyse de l'Eau: Eaux Naturelles, Eaux Résiduaires, Eaux de Mer, Editions Dunod, Paris, France, 1984.

[22] CVRM, Programa ANDAD. Manual do Utilizador, CVRMCentro de Geosistemas, Instituto Superior Técnico, Lisboa, Portugal, 2000.

[23] WHO, Guidelines for Drinking-Water Quality, World Health Organization, Geneva, Switzerland, 3rd edition, 2004.

[24] G. V. Subbarao, O. Ito, K. L. Sahrawat et al., "Scope and strategies for regulation of nitrification in agricultural systems-challenges and opportunities," Critical Reviews in Plant Sciences, vol. 25, no. 4, pp. 303-335, 2006.

[25] A. Landreau and J. C. Roux, Répartition et Évolution des Teneurs en Nitrates dans les Eaux Souterraines en France, Note Technique, BRGM, BRGM, Orléans, France, 1981.

[26] J. D. Hem, Study and Interpretation of the Chemical Characteristics of Natural Water, U. S. Geological Survey, Water Supply Paper 2254, University of Virginia, Charlottesville, VA, USA, 1985.

[27] S. Fertouani, M. Sbaa, M. Vanclooster, and B. Bendra, "Assessing groundwater quality in the irrigated plain of Triffa (north-east Morocco)," Agricultural Water Management, vol. 95, no. 2, pp. 133-142, 2008.

[28] I. Idrissi, M. Zeraouli, M. Addou, A. Mokhtari, and I. A. Soulaymani, "Évaluation de la pollution nitrique de la nappe phréatique de la," Afrique Science: Revue Internationale des Sciences et Technologie, vol. 3, no. 3, pp. 378-390, 2007.

[29] W. Stumm and I. J. Morgn, Aquatic Chemistry: An Introduction Emphasizing Chemical Equilibria in Natural Waters, John Wiley \& Sons, Hoboken, NJ, USA, 2nd edition, 1981.

[30] M. Mozaffari and J. T. Sims, "Phosphorus availability and sorption in an Atlantic coastal plain watershed dominated by animal-based agriculture," Soil Science, vol. 157, no. 2, pp. 97107, 1994.

[31] T. Q. Zhang, A. F. Mackenzie, and B. C. Liang, "Long-term changes in Mehlich-3 extractable $\mathrm{P}$ and $\mathrm{K}$ in a sandy clay loam soil under continues corn (Zea mays L.)," Canadian Journal of Soil Science, vol. 75, no. 3, pp. 361-367, 1995.

[32] C. R. Ramkrisahniah, C. Sadashlvaiah, and G. Ranganna, "Assessment of water quality index for the groundwater in Tumkur Taluk, Karnataka State, India," E-Journal of Chemistry, vol. 6, no. 2, pp. 523-530, 2009.

[33] M. Saeedi, O. Abess, F. Sharifi, and H. Meraji, "Development of groundwater quality index," Environmental Monitoring and Assessment, vol. 163, no. 1-4, pp. 327-335, 2010.

[34] F. Hamzaoui-Azaza, B. Tlili-Zrelli, M. Gueddari, and R. Bouhlila, "Suitability of groundwater of Zeuss-Koutine aquifer (Southern of Tunisia) for domestic and agricultural use," in Water Quality: Indicators, Human Impact and Environmental Health, Chapter 5, pp. 109-130, Nova Science Publishers, Hauppauge, NY, USA, 2012.

[35] K. Srinivasamoorthy, M. Chidambaram, M. V. Prasanna, M. Vasanthavigar, A. John Peter, and P. Anandha, "Identification of major sources controlling groundwater chemistry from a hard rock terrain a case study from Mettur taluk, Salem district, Tamil Nadu, India," Journal of Earth System Sciences, vol. 117, no. 1, pp. 49-58, 2008.

[36] S. M. Yidana, B. Banoeng-Yakubo, and T. M. Akabzaa, "Analysis of groundwater quality using multivariate and spatial analyses in the Keta Basin, Ghana," Journal of African Earth Sciences, vol. 58, no. 2, pp. 220-234, 2010.

[37] R. Jindal and C. Sharma, "Studies on water quality of Sutlej River around Ludhiana with reference to physicochemical parameters," Environmental Monitoring and Assessment, vol. 174, no. 1-4, pp. 417-425, 2011.

[38] D. K. Todd, Groundwater Hydrology, Wiley, New York, NY, USA, 2nd edition, 1980.

[39] L. Gouaidia, O. Gueffaifia, A. Boudoukha, M. L. Hemila, and C. Martin, "Evaluation de la salinité des eaux souterraines utilisées en irrigation et risques de dégradation des sols: exemple de la plaine de Meskiana (Nord-Est Algérien)," Physio-Géo, vol. 6, pp. 141-160, 2012.

[40] M. N. Tijani, "Hydrochemical assessment of groundwater in Moro area, Kwara State, Nigeria," Environmental Geology, vol. 24, no. 3, pp. 194-202, 1994.

[41] L. V. Wilcox, Classification and Use of Irrigation Water, US Department of Agriculture, Circular, Washington, DC, USA, 1955.

[42] K. Srinivasamoorthy, M. Vasanthaviga, K. Vijayaraghavan, R. Sarathidasan, and S. Gopinath, "Hydrochemistry of groundwater in a coastal region of Cuddalore district, Tamil Nadu, India: implication for quality assessment," Arabian Journal of Geosciences, vol. 6, no. 2, pp. 441-454, 2013.

[43] P. A. Domenico and F. W. Schwartz, Physical and Chemical Hydrogeology, Wiley, New York, NY, USA, 1990.

[44] B. Tlili-Zrelli, F. Hamzaoui-Azaza, M. Gueddari, and R. Bouhlila, "Geochemistry and quality assessment of groundwater using graphical and multivariate statistical methods. A case study: Grombalia phreatic aquifer (Northeastern Tunisia)," Arabian Journal of Geosciences, vol. 6, no. 9, pp. 3545-3561, 2013. 

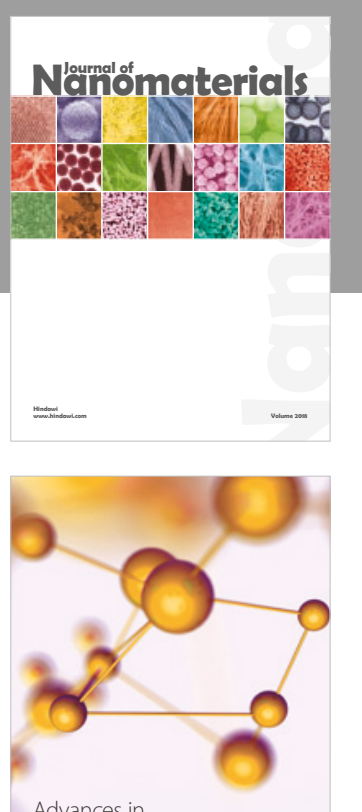

Physical Chemistry
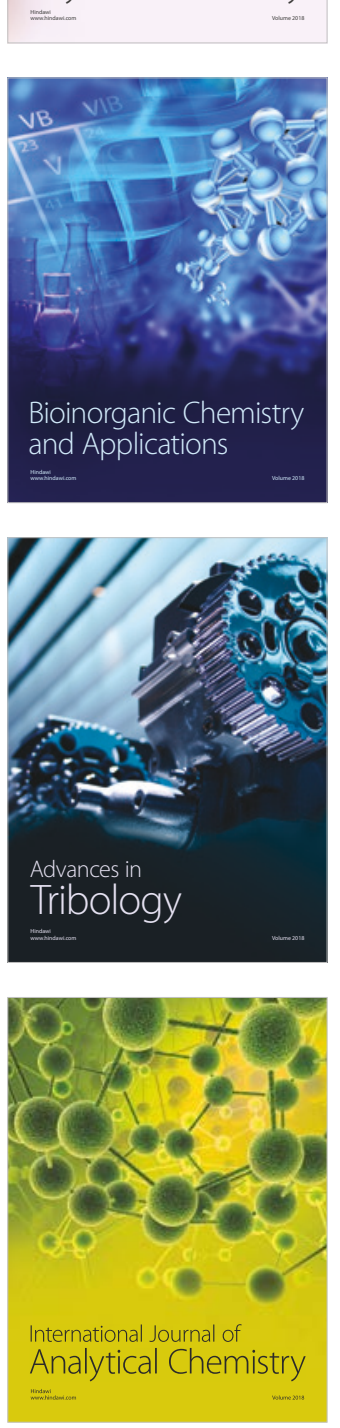

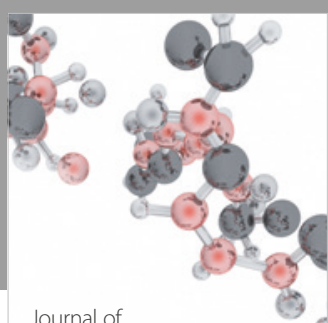

Analytical Methods

in Chemistry

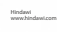

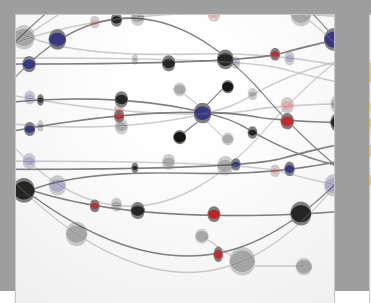

The Scientific World Journal

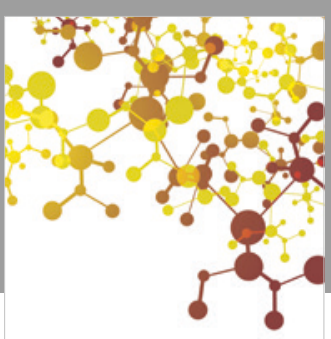

Journal of

Applied Chemistry
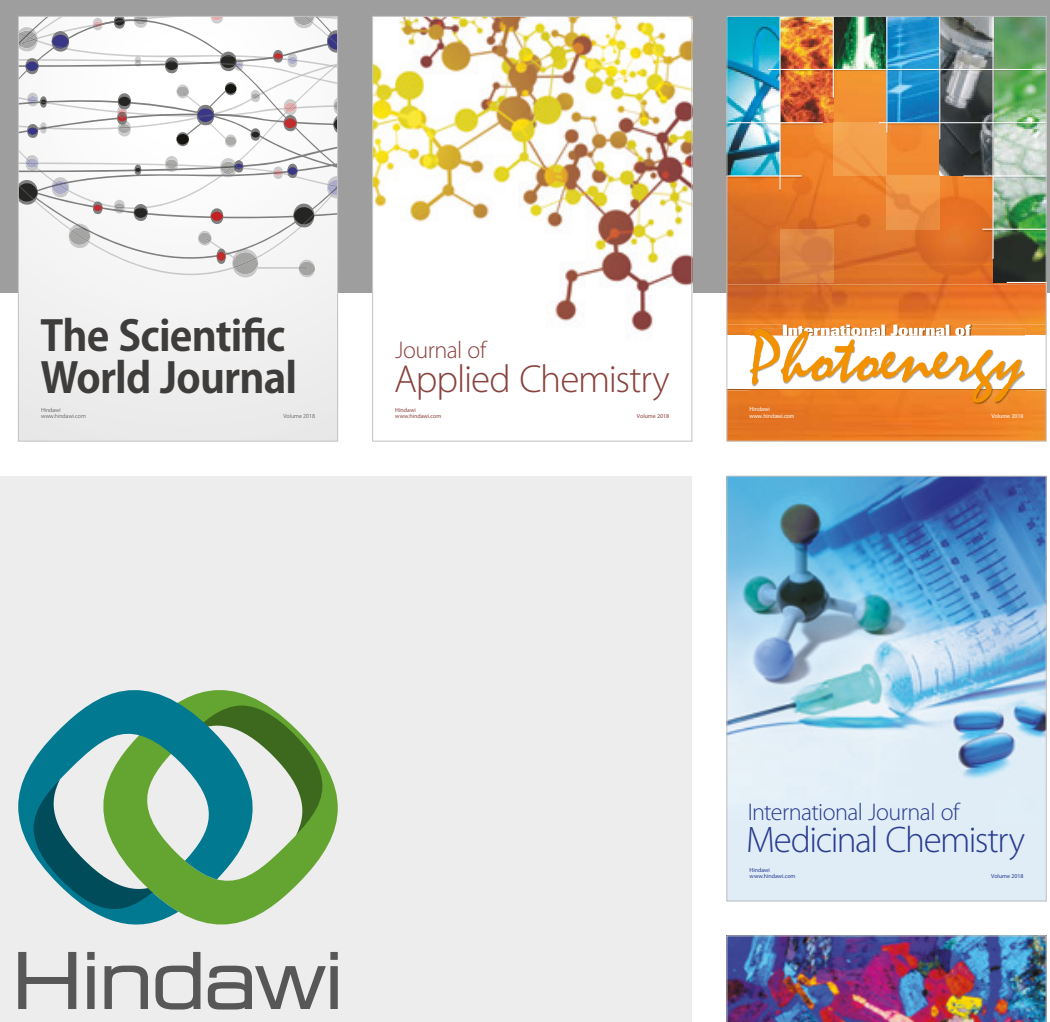

Submit your manuscripts at

www.hindawi.com
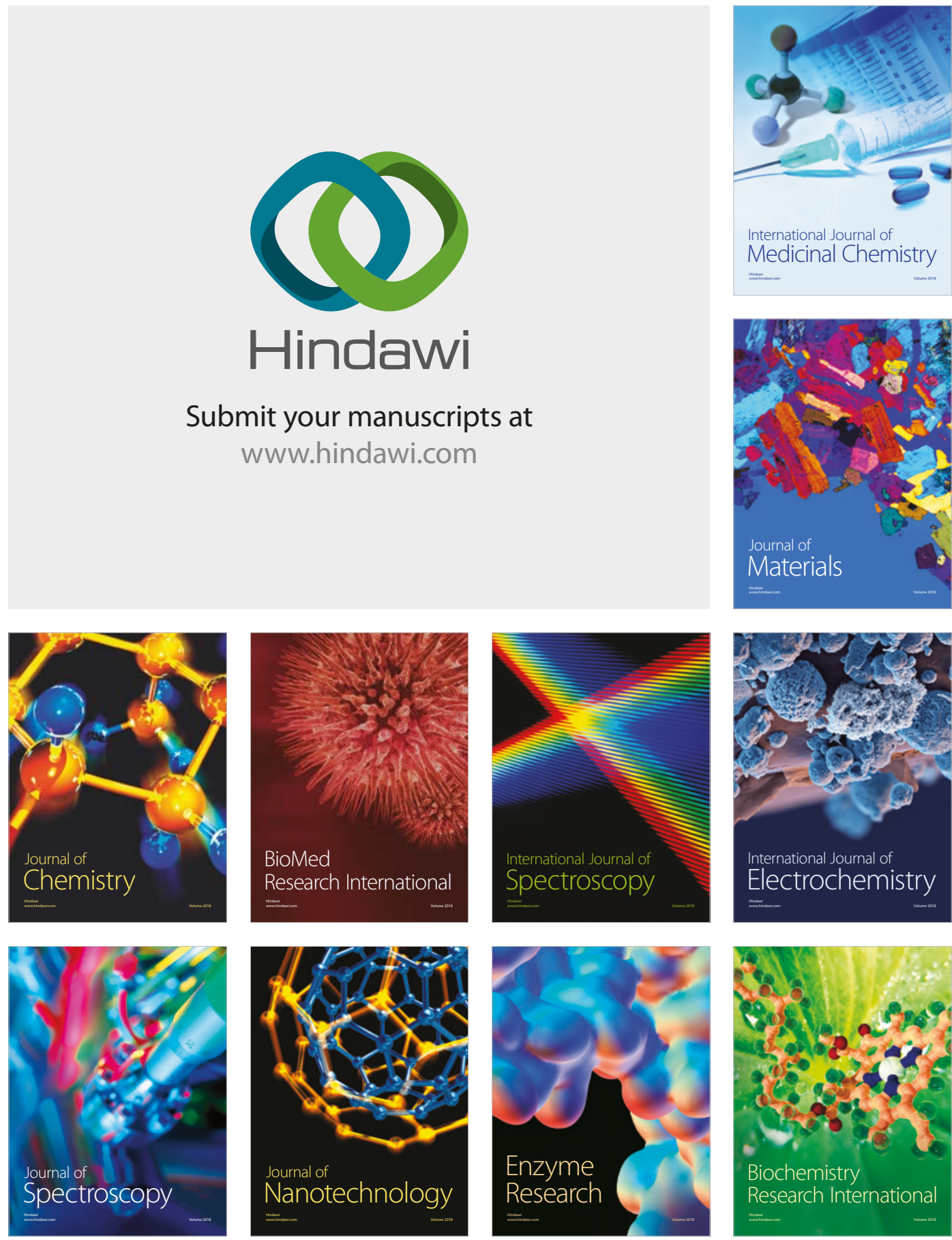
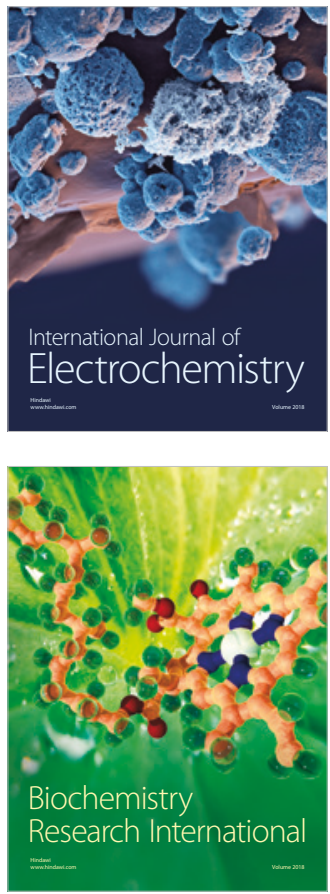